\title{
The ResourcePlan-An Instrument for Resource-Efficient Development of Urban Neighborhoods
}

\author{
Birgitta Hörnschemeyer ${ }^{1, *}$, Anne Söfker-Rieniets ${ }^{2}$, Jan Niesten ${ }^{3}$, Rosalie Arendt ${ }^{4}{ }^{\circledR}$, Jonas Kleckers ${ }^{1}$, \\ Christian Klemm ${ }^{5,6}{ }^{\mathbb{D}}$, Celestin Julian Stretz ${ }^{1}$, Christa Reicher ${ }^{2}$, Winona Grimsehl-Schmitz ${ }^{7}$, Daniel Wirbals ${ }^{3}$, \\ Vanessa Bach ${ }^{4}{ }^{\circ}$, Matthias Finkbeiner ${ }^{4}{ }^{\circ}$, Jens Haberkamp ${ }^{1}$, Janik Budde ${ }^{5} \mathbb{D}$, Peter Vennemann ${ }^{5}$, \\ Gotthard Walter ${ }^{1}$, Sabine Flamme ${ }^{1}$ and Mathias Uhl ${ }^{1}$
}

check for updates

Citation: Hörnschemeyer, B.; Söfker-Rieniets, A.; Niesten, J.; Arendt, R.; Kleckers, J.; Klemm, C.; Stretz, C.J.; Reicher, C.;

Grimsehl-Schmitz, W.; Wirbals, D.; et al. The ResourcePlan-An Instrument for Resource-Efficient Development of Urban Neighborhoods. Sustainability 2022, 14, 1522. https://doi.org/10.3390/ su14031522

Academic Editors:

Thomas Luetzkendorf and Rebekka Volk

Received: 17 December 2021

Accepted: 24 January 2022

Published: 28 January 2022

Publisher's Note: MDPI stays neutral with regard to jurisdictional claims in published maps and institutional affiliations.

Copyright: (C) 2022 by the authors. Licensee MDPI, Basel, Switzerland. This article is an open access article distributed under the terms and conditions of the Creative Commons Attribution (CC BY) license (https:// creativecommons.org/licenses/by/ $4.0 /)$.
1 Institute for Infrastructure Water Resources Environment, Muenster University of Applied Sciences, 48149 Muenster, Germany; kleckers@fh-muenster.de (J.K.); c.stretz@fh-muenster.de (C.J.S.); haberkamp@fh-muenster.de (J.H.); gwalter@fh-muenster.de (G.W.); flamme@fh-muenster.de (S.F.); uhl@fh-muenster.de (M.U.)

2 Institute for Urban Design and European Urbanism, RWTH Aachen University, 52062 Aachen, Germany; soefker@staedtebau.rwth-aachen.de (A.S.-R.); reicher@staedtebau.rwth-aachen.de (C.R.)

3 Department of Environment and Urban Planning, City of Herne, 44652 Herne, Germany; jan.niesten@herne.de (J.N.); daniel.wirbals@herne.de (D.W.)

4 Department of Sustainable Engineering, Institute of Environmental Technology, Technische Universität Berlin, 10623 Berlin, Germany; arendt@tu-berlin.de (R.A.); vanessa.bach@tu-berlin.de (V.B.); matthias.finkbeiner@tu-berlin.de (M.F.)

5 Department of Energy, Building Services and Environmental Engineering, Muenster University of Applied Sciences, 48565 Steinfurt, Germany; christian.klemm@fh-muenster.de (C.K.); janik.budde@fh-muenster.de (J.B.); vennemann@fh-muenster.de (P.V.)

6 Department of Energy and Environmental Management, Europa-Universität Flensburg, 24943 Flensburg, Germany

7 Department of Civil Engineering and Traffic, City of Herne, 44652 Herne, Germany; winona.grimsehl-schmitz@herne.de

* Correspondence: b.hoernschemeyer@fh-muenster.de

\begin{abstract}
In Germany, the current sectoral urban planning often leads to inefficient use of resources, partly because municipalities lack integrated planning instruments and argumentation strength toward politics, investors, or citizens. The paper develops the ResourcePlan as (i) legal and (ii) a planning instrument to support the efficient use of resources in urban neighborhoods. The integrative, multi-methodological approach addresses the use of natural resources in the building and infrastructural sectors of (i) water (storm- and wastewater) management, (ii) construction and maintenance of buildings and infrastructure, (iii) urban energy system planning, and (iv) land-use planning. First, the development as legal instrument is carried out, providing (i) premises for integrating resource protection at all legal levels and (ii) options for implementing the ResourcePlan within German municipal structures. Second, the evaluation framework for resource efficiency of the urban neighborhoods is set up for usage as a planning instrument. The framework provides a two-stage process that runs through the phases of setting up and implementing the ResourcePlan. (Eco)system services are evaluated as well as life cycle assessment and economic aspects. As a legal instrument, the ResourcePlan integrates resource protection into municipal planning and decision-making processes. The multi-methodological evaluation framework helps to assess inter-disciplinary resource efficiency, supports the spatial identification of synergies and conflicting goals, and contributes to transparent, resource-optimized planning decisions.
\end{abstract}

Keywords: resource efficiency; resource management; urban neighborhood; urban planning; urban development; Germany; water; building materials; energy; land 


\section{Introduction}

Urbanization is the future mega-trend. The German Advisory Council on Global Change identifies urbanization as one of the most outstanding challenges for social and infrastructural development of present and future [1]. Although urbanization can increase the inhabitant's quality of live by, e.g., raising availability of health services or social and infrastructural facilities [2,3], it can also bring environmental and social problems.

In 2005, the Millennium Ecosystem Assessment stated that "human activity is putting such strain on the natural functions of earth that the ability of the planet's ecosystems to sustain future generations can no longer be taken for granted" [4]. The use and overuse of natural resources such as water, raw materials, and land threaten the Earth system's resilient state [5,6]. Seto et al. [7] declare, "the conversion of earth's land surface to urban uses is one of the most irreversible human impacts on the global biosphere". Covering less than $3 \%$ of the global terrestrial surface [8], cities consume about $75 \%$ of the world's energy [9] and $60 \%$ of residential water resources [8]. The excessive use of resources goes hand in hand with advancing climate change. If global warming proceeds in the current trend, the loss and damage to ecosystem services will lead to a lack of human well-being, livelihoods, and health $[10,11]$.

A clear need for change in resource use for urban development can be seen (e.g., [12,13]). In 2005, the World Conservation Union introduced the three pillars of sustainable development (Ecological-Social-Economic) [14,15] and therefore seeks to bring attention to the role of holistic decision making. With the declaration of the 17 Sustainable Development Goals [16], the United Nations Sustainable Development Summit marked a turning point for urban development in 2015, addressing questions of water, infrastructure, biodiversity, and climate change. Similar alignments are promoted by the Leipzig Charter $[17,18]$, the New Urban Agenda [19], the Paris Agreement [20], and the European Commission's Green Deal [21].

Urban development influences the use of natural resources water, raw materials, and land. When discussing an efficient resource use, "resource efficiency" can be defined as "ratio of a certain benefit or result to the resource input required to achieve it" [22]. Different sectors-in the sense of fields of building and infrastructural resource management-can be identified as relevant for urban development, such as water (storm- and wastewater) management, construction and maintenance of buildings and infrastructure (building material cycles), urban energy system planning, and land-use planning. For all of them, resource management concepts already exist that pursue sectoral resource efficiency: Firstly, stormwater management impacts the urban water and energy cycle [23]. The principles for water wise cities [24] lead to recursive planning and stepwise realization ("no-regret approach"). Water Sensitive Urban Design [25,26] combines "retention, detention and use" in "blue-green infrastructure" with high design quality for water and land. Secondly, the separation of different domestic wastewater streams such as black and gray water at the source prevents dilution of more concentrated wastewater by less concentrated wastewater and therefore facilitates efficient treatment and enables efficient recycling of water and nutrients [27]. Thirdly, sustainable management of building material cycles is possible through knowledge of material quantities, qualities, and flows [28,29]. Valuation indices and procedures for resources at the regional scale are transforming from mass-based to integrated approaches that consider resource availability as well as environmental impacts [30-32]. Fourth, in urban energy system planning, there are a variety of technologies and measures that can lead to an improvement in sustainability. These technologies and measures can be summarized under the three sub-strategies of energy efficiency $[33,34]$, energy sufficiency [34,35], and energy consistency [36]. Fifth, the use of land is mainly managed through the urban land-use planning (in Germany in accordance to the Federal Building Code BauGB [37]). Environmental land-use assessments are examined in accordance to the Federal Nature Conservation Act of Germany [38] using methods such as the biotope value procedure [39]. 
However, sectoral resource management strategies do not consider inter-disciplinary interactions and conflicting interests. Besides, political discourse about sustainable solutions and conflicting goals of different stakeholders [40,41] inhibit the implementation of transformation strategies. Therefore, municipalities need integrated concepts (i) to evaluate resource efficiency inter-disciplinary [42] and (ii) to support sustainable decision making under discourse and conflicting interests [43].

One existing option to evaluate the city's environmental impacts in terms of its resource use on global level is life cycle assessment (LCA) [44,45]. A number of studies are available for resource recovery in building construction [46-48], urban water supply and wastewater disposal [49-52], and urban land management [53]. Concepts for integrated evaluations exist on neighborhood $[54,55]$ and city scales $[56,57]$. However, LCA in an urban context is complex and challenging because inter-disciplinary, dynamic aspects have to be considered, and system boundaries cannot always be clearly defined [58]. Approaches to integrate local effects, such as urban heat islands [59], are still under development.

As another option, various decision support instruments for urban contexts lead to sustainable solutions. They exist for inter-disciplinary assessments [60-62] or sectoral decision making [63-67]. However, in terms of the mentioned political discourse and conflicting goals, they lack of legal liability, weighting systems, and need-based evaluation approaches to consider all perspectives [68].

In contrast, governing frameworks such as environmental impact assessment [69], strategic environmental assessment [70], or urban climate maps [71] identify the local consequences of a proposed action on a sectoral scale. However, due to their environmental focus, they do not fully incorporate inter-disciplinary interactions. Methods to assess multi-functionality at relevant scale are lacking [72]. Moreover, their low transparency and accountability are highly obstructive to holistic implementation in community policy and decision making [73-75].

Analyzing the demands and limitations of current urban resource management practices, the main lacks can be summarized as (i) missing integrated municipal concepts or instruments that (ii) support holistic, inter-disciplinary evaluation and decision making and (iii) promote assertiveness of those decisions. Therefore, the aim of this study is to research integrated planning approaches for efficient use of urban resources and to develop an instrument for (i) evaluating inter-disciplinary resource efficiency as well as (ii) supporting legal enforcement of developed resource management strategies. The instrument to be developed are subject to binding constraints such as:

(i) The resource efficiency evaluation should consider the three pillars of sustainable development (Ecological-Social-Economic) as well as the relevant urban building and infrastructural resource management sectors (water, building materials, energy, and land), which can be supplemented modularly on demand.

(ii) Resource efficiency evaluation should be possible inter- as well as intra-disciplinarily, including all necessary internal and external drivers.

(iii) For multi-functional use in the development of comprehensive strategies on the one hand, and specific decision making on the other hand, the instrument should be scalable from the neighborhood to the parcel level.

(iv) In addition, the results should be the basis for a legal realization within the existing municipal structures. The development is completed based on German law.

The instrument is going to be called "ResourcePlan". It will be developed as a package of modular instruments. The aim of this paper is to present its theoretical conceptualization and to test applicability with an exemplary case study.

\section{Materials and Methods}

\subsection{Conceptual Approach}

A "ResourcePlan" that supports the successive development of a sustainable, efficient use of resources in different neighborhood typologies is defined. The approach addresses the increase of efficient resource use at relevant urban building and infrastructural resource 
management sectors: (i) water (storm- and wastewater) management, (ii) construction and maintenance of buildings and infrastructure, (iii) urban energy system planning, and (iv) land-use planning (Section 2.2.2). This exemplary selection of urban resource management sectors can be expanded in a modular form.

The structure for development is summarized in Figure 1. The ResourcePlan is designed as a two-component instrument (Figure 1, orange). For legalizing resource management strategies within the existing municipal structures, first, the ResourcePlan is conceptualized as a legal instrument. Second, an inter-disciplinary decision support framework is designed for usage as a planning instrument.

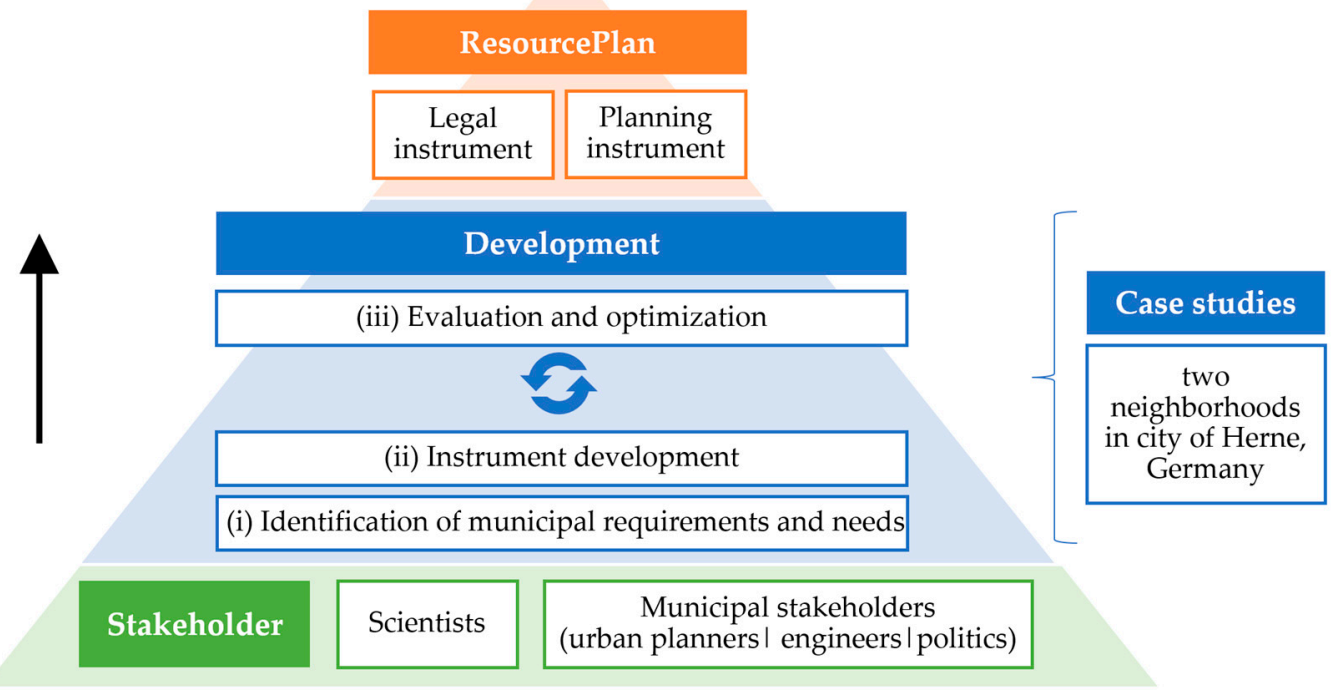

Figure 1. Conceptual approach for development of the ResourcePlan.

The development follows an explorative approach and is based on close, transdisciplinary exchange between scientists and stakeholders of the municipalities (Figure 1, green). On the scientific side, experts for all resources under consideration are involved. On the municipal side, urban planners, engineers, and politicians from the city of Herne, as the main partner, and from eight other associated municipalities participate.

All topics are discussed within a recursive three-step process of (i) identification of municipal requirements and needs, (ii) instrument development, and (iii) evaluation and optimization (Figure 1, blue). The municipal requirements and needs were established by the stakeholders at the beginning of the project. The defined aspects go back to experiences from past projects, identified barriers to current structures, and requirements arising from future challenges. The prioritization was conducted in collaborative discussion of all stakeholders. Afterward, the aspects were formulated as "framing principles" for both instrument components for use as evaluation und optimization criteria. They are described within the next sections (Sections 2.1.1 and 2.1.2).

The instrument development is mainly performed by the scientists in communication with the municipal stakeholders. The municipal stakeholders evaluate the proposed solutions in terms of the framing principles. At all times, the development is conducted based on two case studies in the city of Herne (Section 2.3), which are stepwise and used to validate the conceptual methods under development.

\subsubsection{Analysis of Legal Implementation (Legal Instrument)}

The development of the ResourcePlan as a legal instrument is completed inductively based on existing legal structures. The study is performed in two steps:

First, premises for integrating resource protection at all legal levels-from EU- to municipal level—are derived (Section 3.2.1). To obtain an object of comparison, the current 
legal structures for climate protection and their effects on the processes of local government are examined. For this purpose, an analysis of the development of legal structures for climate protection on the EU, federal, regional, and municipal levels is completed. From this, premises for resource protection are derived.

Second, options for legalizing the ResourcePlan within municipal structures are specified (Section 3.2.2). For this purpose, existing formal and informal instruments are evaluated regarding (i) the depth of impact, (ii) the sectoral influence, (iii) the relevance of ownership, (iv) the suitability of different life cycle status (new/existing), and (v) the legal bindingness. The framing principles for the development of the legal instrument and its recursive evaluation and optimization are:

1. Permanent task: Resource efficiency and resource protection are to become a permanent municipal task within medium- and long-term planning;

2. Inter-/trans-disciplinarity: Early and integrative cooperation of all disciplines;

3. Future ability: Ensure updatability and transferability;

4. Communication: Transparent communication to addressees: internal administration, citizens, investors;

5. Practical orientation: Comprehensible and user-oriented structure;

6. Integration: Integrating resource planning as a major concern in municipal management structures.

\subsubsection{Inter-Disciplinary Evaluation Framework (Planning Instrument)}

An evaluation system is developed to analyze, measure, and evaluate resource efficiency in the urban neighborhood. The system is designed as a multi-methodological evaluation process, going back to (i) the three pillars of sustainable development (EcologicalSocial-Economic) as well as (ii) the relevant urban building and infrastructural resource management sectors (water, building materials, energy, and land). On the one hand, LCA is chosen as one evaluation method to cover aspects of environmental impacts through the whole life cycle of the neighborhood. On the other hand, local system functionality and low environmental impact must be ensured, as well. To cover the sectoral system states as well as their interactions, sectoral resource efficiency evaluations are performed as well as their summary within a common framework. Therefore, the development of the planning instrument is completed modularly.

The main concept starts from a common definition of resource efficiency (Section 2.2.3). Based on this, the approach is transferred and specified sectoral. Existing sectoral evaluation principles are taken as a basis and adapted to the specific needs of the ResourcePlan framework. To ensure linkability of the sectoral evaluation results and practicability at the municipal level, the system is based on geodata. Key aspects-such as the overall approach of the evaluation system, the relevance of the selected evaluation indicators and the complexity of the data management-are discussed with the municipal stakeholders.

The framing principles for the development of the planning instrument and its recursive evaluation and optimization are:

1. Transferability: The evaluation framework must be transferable to other neighborhoods and municipalities;

2. Practical relevance: Results must be application-oriented and easy to understand. Planning targets and solution strategies that can be used for orientation and success control in future projects are helpful;

3. Relative assessment: Due to the different conditions of different neighborhoods, a relative assessment is preferable to an absolute assessment;

4. Adaptability: Due to the different parameters (qualitative, quantitative) of the various sectors, an open and flexible approach is sought;

5. National guidance: Criteria must be aligned to nationwide objectives;

6. Updateability: The approach must be adaptable to new scientific knowledge or changing objectives; 
7. Effort: The procedure should be resource-saving, regarding financial and human resources of the municipal administration.

\subsection{Underlying Definitions}

\subsubsection{Balance Area: Urban Neighborhoods}

The neighborhood was chosen as the area of balancing. In contrast to administrative delimitations of city districts, the neighborhood has boundaries that are not precisely defined. According to Olaf Schnur, the neighborhood is a "[ ... ] vaguely contoured centre-place of everyday life worlds [ ... ] whose intersections are represented in the spatial-identificatory context of a manageable residential environment" [76]. This goes back to the fact that the core zone of a neighborhood is usually perceived as a reference space by the majority of residents, while the outer boundaries are often defined differently [77]. Therefore, the different systems considered here are understood as sectoral functional units, representing the sectors water, building materials, energy, and land. To ensure a coordinated space for the evaluation, the inter-section area-the core zone of the sectoral functional units-is defined as control space (Figure 2).

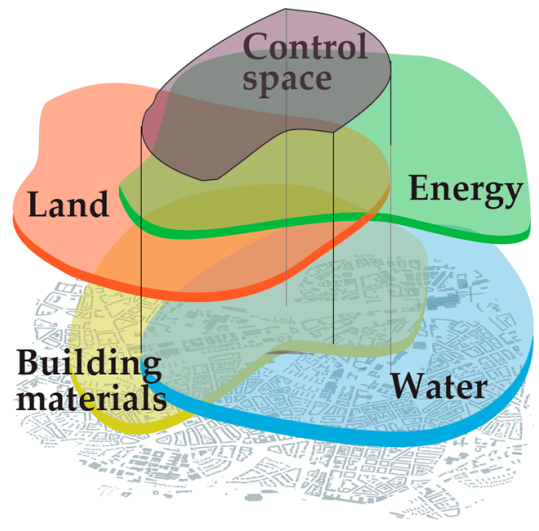

\section{Legend}
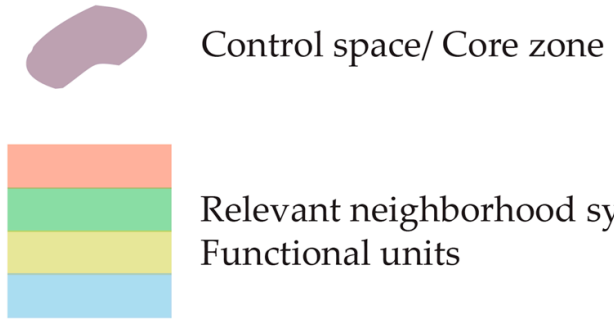

Relevant neighborhood systems/ Functional units

Figure 2. Neighborhood systems and control space. Base map extracted from Openstreetmap [78], licensed by CC-BY-SA 2.0 [79].

\subsubsection{Resource Management under Consideration}

The paper addresses the resources water, raw materials, and land. Different sectorsin the sense of fields of building and infrastructural resource management-can be defined, which manage or influence the use those resources. Each sector forms a (infrastructural) system. Several interactions with other systems (intra-, inter-, or trans-disciplinary) are possible. For the ResourcePlan, resource efficiency evaluation is performed for each sector as well as a summarizing assessment. The sectors under consideration can be defined as follows. The assessment of further sectors can be added on demand.

Water: The water sector includes all urban water management infrastructure systems for the use of potable water, reuse, discharge and treatment of wastewater and stormwater. Water management should be in accordance with the principles of water-wise cities [24]. Therefore, the focus is on the use and recycling of existing resources such as wastewater and stormwater, preservation of natural water balance, pollution control (total suspended solids, heavy metals, nutrients, or biocides), and resilience to future extreme weather events (drought, heavy rain).

Building materials: The sector "building materials" considers the materials used in building construction and civil engineering with regard to their quantity and changes over time. In particular, the inventory in the so-called anthropogenic material store as well as the release of materials for the areas of buildings, wastewater infrastructure, roads, and paths are observed. The aim is an integrated and foresighted material flow management in civil engineering and step-by-step implementation of a closed-loop recycling management. 
Energy: In the context of energy systems, energy is usually referred to the provision of "desired energy services, rather than [energy] as an end in itself" [80]. Urban energy systems can be defined as the "combined process of acquiring and using energy" [81] in spatial units with a high density and differentiation of usage sectors [82,83], as well as energy sectors (e.g., heat, electricity, fuels) $[83,84]$. The provision of energy requires a wide range of resource input; hence, there is a close link to other resource sectors. When optimizing urban energy systems, minimizing greenhouse gas emissions, energy costs, and energy demands are appropriate objectives [83].

Land: Land comprises the geometrically definable section of the earth's surface within a neighborhood. It is divided into individual areas of different properties. The spaces lying above and below the earth's surface and likewise inclined, vertical, or curved planes (roof surfaces, facades, story levels, and civil engineering) are projected onto this section of the earth's surface.

\subsubsection{Resource Efficiency}

The selected common definition of the term "resource efficiency" by the Federal Environment Agency is "ratio of a certain benefit or result to the resource input required to achieve it" [22]. The term "benefit" is defined here as the "ability of a good to satisfy a certain need [ ... ]" [85] and is only present when the use of the good-the commissioningtakes place by a person or another living being.

As described in Section 2.1.2, this definition is the basis of the main evaluation framework's approach and is transferred individually to the assessments of the sectors mentioned in Section 2.2.2.

\subsection{Case Study}

Two neighborhoods in Herne, a city in North Rhine Westphalia, Germany, were selected for theoretical development of the ResourcePlan (Section 2.1). The selected neighborhoods "Baukau" and "Pantringshof" show differences due to their urban and social structures, and their infrastructures are located at different positions in the life cycle (e.g., canalization and road conditions). This guarantees a diverse empirical basis and the broadest possible testing of the intended evaluation methods.

For this paper, a sub-neighborhood was chosen as a case study for exemplary application of the ResourcePlan. The sub-neighborhood under consideration (Figure 3) is located in the middle of Herne-Baukau. With an area of 14.6 ha, it consists out of semi-detached houses and their gardens in the south, apartment houses in the east, and a business building and its parking lot in the northeast. In the northwestern corner is a fallow without any further use. Garages can be found at the western side. The area is framed by three roads. The northern and eastern roads "Westring" and "Bahnhofstraße" are highly frequented main roads. The southern road "Weidkamp" is a low-frequented residential street. The western road is a dead end road with a footpath connection to "Westring". 


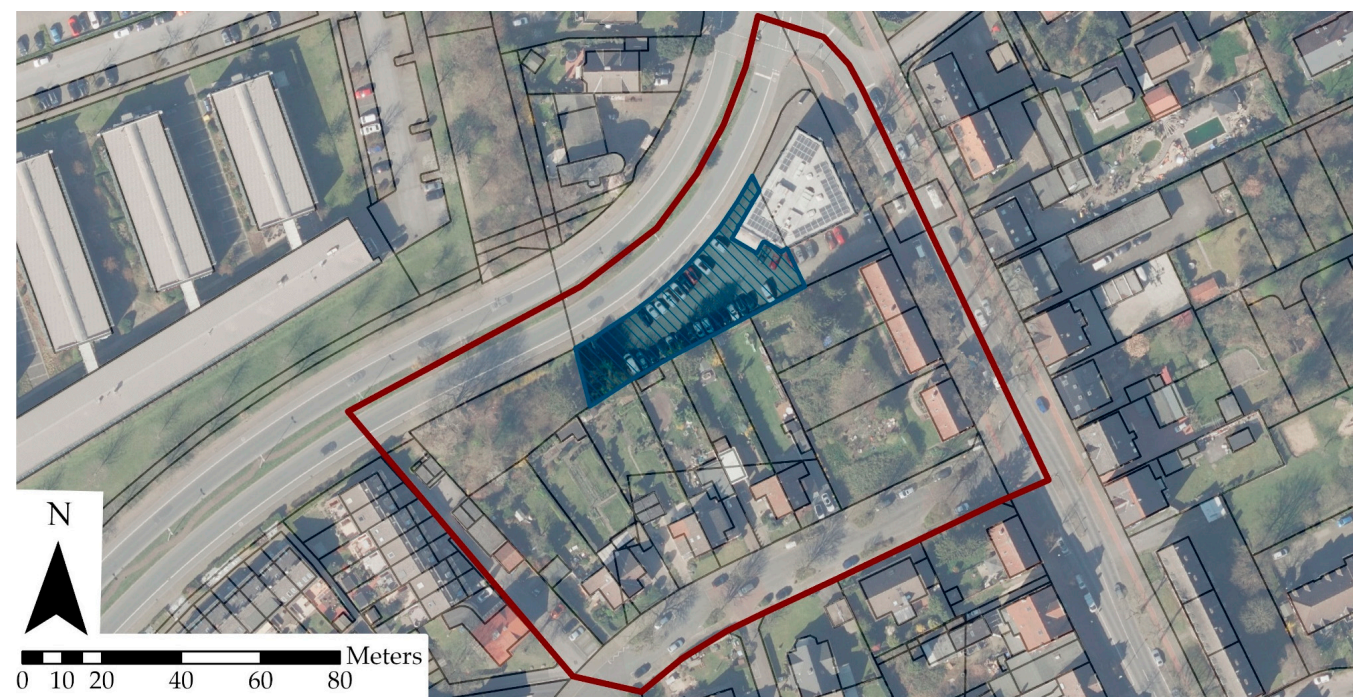

Figure 3. Sub-neighborhood under consideration (red line) for exemplary ResourcePlan application. Parking lot for exemplary decision making is marked in blue. Base map (orthophoto and cadaster) extracted from Bezirksregierung Köln Geobasis NRW [86], licensed by data license Germany-ZeroVersion 2.0 [87].

\section{Results}

The findings are presented within four steps: First, the ResourcePlan is defined (Section 3.1). Second, (i) premises for integrating resource protection at all legal levels and (ii) options for implementing the ResourcePlan within municipal structures are provided for setting up the ResourcePlan as a legal instrument (Section 3.2). Third, an evaluation framework is derived to ensure the use the ResourcePlan as planning instrument (Section 3.3). Fourth, the new instruments and findings are applied and validated in an exemplary case study (Section 3.4).

\subsection{ResourcePlan-Definition}

The ResourcePlan is a two-component instrument for improving resource use in urban neighborhoods.

The ResourcePlan is a legal instrument that promotes and legally establishes a coordinated and efficient use of resources in the neighborhood at the municipal level. It consists of (i) the master plan, which spatially locates deficit and potential areas as well as solution strategies, and (ii) planning goals that allow for simple feasibility checks and success controls in very early planning phases. The legal implementation in the municipal structures is conducted as a set of instruments by integrating the strategies from the master plan and the planning goals into existing formal and informal instruments.

A ResourcePlan evaluation framework is being developed as a planning instrument that measures, balances, and evaluates the efficient use of resources in the neighborhood. Using the multi-methodological planning approach, the neighborhood can be analyzed in order to determine needs, to set planning goals, to identify deficit and potential areas for transformation, and to make planning decisions.

The approach provides a two-stage process that goes through the phases of setting up and implementing the ResourcePlan (Figure 4). 
tion, the various measures on federal and regional level provide the basis for promoting climate protection in the municipality (see entire empirical study at Supplementary Materials S1). In summary, the empirical case study on legal structures for climate protection reveals the following successfully implemented premises that guarantee the anchoring of climate protection:

- Consistent integration of climate protection at all legal sources;

- Close coordination between the individual climate-related legal sources;

- Development of a strategy for climate protection and recommendations for action on federal and regional level to promote climate protection;

- $\quad$ Transfer of knowledge from the federal and regional levels to the municipal level.

Climate protection can therefore be seen as a good example of legally strengthening resource protection at the international and national level, promoting it nationally through suitable measures and becoming more capable of acting on the municipal level.

In contrast to climate protection, the current structures for resource protection can be briefly described as follows: In the various agreements, treaties, and legislations on different political levels, resource protection is already partly taken into account. At the EU level, for example, the Lisbon Treaty in Article 191 TFEU refers to the "prudent and rational utilisation of natural resources" [88]. The European Green Deal also mentions a decoupling of economic growth from the use of resources [21]. On the federal level, the issue of resource protection is dealt within the German Federal Government's Resource Efficiency Program (ProgRess) [89]. The aspects of sustainable building and sustainable urban development are becoming increasingly important. On the regional level, in the Climate Protection Act of the State of North Rhine-Westphalia, Germany, in Section 4 (4), KSG attaches importance to increasing resource protection as well as resource and energy efficiency, energy saving, and the expansion of renewable energies [90].

Derived from the above findings on climate protection, the anchoring of resource protection in all legal sources and the ability of the municipality to act must be achieved in the future by the following means:

- Consistent integration: The target of resource protection should be laid down in all legal sources. Building on one another, resource protection is to be anchored in law on the federal, regional, and municipal level. Finally, the operationalization level is the municipal level, on which resource protection is implemented in various strands and procedures as part of the district transformation. In addition, resource protection must be integrated much more closely into existing procedures on the neighborhood level. In urban planning, there are various options for integrating resource protection and resource efficiency more firmly. Similar to climate protection, in Section 1 (5) of the Federal Building Code of Germany [37], the protection of resources could be inserted as a principle in the land-use planning.

- Close coordination: Close coordination between the individual resource-related legal sources is necessary for easy application. Furthermore, new, additional procedures in the context of urban land use planning are to be avoided in order to conserve human and financial resources on the municipal level. Since the task of resource protection exists in many environmental and economic areas, there should also be an effort to develop the existing laws in a way that is suitable for resource protection.

- Recommendations for action: At the same time, the required increase in resource efficiency should be implemented through a resource (protection) plan on a federal or regional level, similar to the climate protection plan. This does not contain any obligations but recommends a large number of measures and supports the implementation with funding offers.

- $\quad$ Transfer of knowledge: Together with the recommendations and the promotion of measures, an organized transfer of knowledge on the follow-up costs of resource consumption and cost savings through targeted measures should be conveyed in training courses. The municipalities ultimately decide on the specific measures for resource 
efficiency. This ensures long-term resilience and enables the site-specific requirements to be adapted at the neighborhood level.

\subsubsection{Implementation Options for Increasing Resource Protection in Municipal Legal} Structures

In the context of the ResourcePlan, the municipal instruments are supposed to implement solution strategies and planning goals derived during Phase I (Figure 4). To define implementation options, an analysis of formal and informal urban planning instruments is carried out. The municipal instruments are analyzed regarding criteria such as (i) the depth of impact, (ii) the sectoral influence, (iii) the relevance of ownership, (iv) the suitability of different life cycle status (new/existing), and (v) the legal bindingness. A summary is given in Table 1.

The zoning plan (1), as a formal instrument, has the option of legally defining resourcerelevant aspects, for example, energy or water management. However, resource protection has so far not been a principle in urban land-use planning and is therefore not a matter of consideration in the building code ( $\$ 1$ BauGB [37]). For this purpose, informal plans such as the urban development draft (2) can serve as a preliminary stage in order to address resource-relevant aspects. However, this instrument is not legally binding. Project-related legal zoning plans (3) are a good instrument for agreeing on measures to protect resources directly with the investor. The sector's water, energy, land, and building materials can be addressed directly, and the plan is legally binding.

Furthermore, urban planning instruments such as concept awarding (4) or urban development contracts (5) have a greater scope of action to influence the protection of resources while at the same time ensuring legal certainty.

Informal plans with related topics, such as the integrated climate protection concept or the master plan for sustainable mobility (6), serve as an important basis for implementing measures in the city. A master plan for resource protection would bring the topic more into focus. At the same time, the individual sectors could be addressed directly and recommendations for action could be issued.

The selection of the instrument or a mix of instruments always depends on the framework conditions. A decisive criterion here is the ownership in terms of private or a public land. At the same time, the existing building and the new construction require different instruments. If the municipality is the owner of the land, a concept award is a suitable instrument, for example. If a new construction is to be built on a private area, the projectrelated legal zoning plan or the urban development contract can be used as an instrument to promote the protection of resources. In the case of an existing building with private ownership, the selection of instruments is limited. However, funding programs (7) or advisory (8) can support measures to protect resources.

In summary, the analysis of the municipal formal and informal instruments has shown that various instruments are already in place to implement the solution strategies and planning goals of the ResourcePlan. Although further legal framework conditions have to be created in order to promote resource protection, resource planning can already be positively influenced by those urban planning instruments. Various criteria must be taken into account when selecting the instruments (Table 1). The choice should be made individually for the specific set. If the implementation is carried out effectively, the resource management measures can be established precisely. 
Table 1. Analysis on usability of municipal instruments for implementing measures of resource management.

\begin{tabular}{|c|c|c|c|c|c|c|c|c|c|}
\hline \multirow{2}{*}{ ID } & \multirow{2}{*}{ Instrument } & \multirow{2}{*}{$\begin{array}{c}\text { Formal or } \\
\text { Informal } \\
\text { Instrument }\end{array}$} & \multicolumn{4}{|c|}{ Sectoral Influence ${ }^{1,2}$} & \multirow{2}{*}{$\begin{array}{l}\text { Relevance of } \\
\text { Ownership }\end{array}$} & \multirow{2}{*}{$\begin{array}{l}\text { New Construction or } \\
\text { Existing Building }\end{array}$} & \multirow{2}{*}{$\begin{array}{c}\text { Legal } \\
\text { Bindingness }\end{array}$} \\
\hline & & & $\mathbf{W}$ & B & $\mathbf{E}$ & $\mathbf{L}$ & & & \\
\hline (1) & Zoning Plan & Formal & + & $\mathrm{o}$ & + & ++ & Non-existent & No relevance & Yes \\
\hline$(2)$ & $\begin{array}{c}\text { Urban } \\
\text { development } \\
\text { draft }\end{array}$ & Informal & + & + & + & ++ & $\begin{array}{l}\text { Existent; e.g., interim } \\
\text { acquisition } \\
\text { of land by the } \\
\text { municipality }\end{array}$ & $\begin{array}{c}\text { Relevance; new } \\
\text { construction } \\
\text { is preferably addressed }\end{array}$ & No \\
\hline (3) & $\begin{array}{l}\text { Project- } \\
\text { related } \\
\text { legal zoning } \\
\text { plan }\end{array}$ & Formal & ++ & + & ++ & ++ & $\begin{array}{l}\text { Existent; an investor } \\
\text { is usually } \\
\text { the owner of the land }\end{array}$ & $\begin{array}{c}\text { Relevance; new } \\
\text { construction } \\
\text { is preferably addressed }\end{array}$ & Yes \\
\hline$(4)$ & $\begin{array}{l}\text { Concept } \\
\text { awarding }\end{array}$ & Informal & ++ & ++ & ++ & ++ & $\begin{array}{l}\text { Existent; the } \\
\text { municipality } \\
\text { must be the owner of } \\
\text { the land }\end{array}$ & $\begin{array}{c}\text { Relevance; new } \\
\text { construction } \\
\text { is preferably addressed }\end{array}$ & $\begin{array}{c}\text { Yes } \\
\text { (contract) }\end{array}$ \\
\hline (5) & $\begin{array}{c}\text { Urban } \\
\text { development } \\
\text { contract }\end{array}$ & Formal & ++ & + & ++ & ++ & $\begin{array}{l}\text { Existent; land is } \\
\text { usually } \\
\text { privately owned }\end{array}$ & $\begin{array}{c}\text { Relevance; new } \\
\text { construction } \\
\text { is preferably addressed }\end{array}$ & Yes \\
\hline (6) & Master plan & Informal & ++ & ++ & ++ & ++ & Non-existent & No relevance & No \\
\hline (7) & $\begin{array}{l}\text { Funding } \\
\text { program }\end{array}$ & Informal & + & + & + & o & $\begin{array}{l}\text { Existent; private } \\
\text { owners } \\
\text { are particularly } \\
\text { addressed }\end{array}$ & No relevance & No \\
\hline$(8)$ & Advisory & Informal & + & + & + & o & $\begin{array}{l}\text { Existent; private } \\
\text { owners } \\
\text { are particularly } \\
\text { addressed }\end{array}$ & $\begin{array}{c}\text { Relevance; new } \\
\text { construction } \\
\text { is preferably addressed }\end{array}$ & No \\
\hline
\end{tabular}

\footnotetext{
${ }^{1}$ abbreviations of sectors: $\mathrm{W}=$ Water, $\mathrm{B}=$ Building materials, $\mathrm{E}=$ Energy, $\mathrm{L}=$ Land. ${ }^{2}$ Scale: $\mathrm{o}=$ minor, $+=$ medium,$++=$ major.
} 


\subsection{ResourcePlan as Planning Instrument}

\subsubsection{Definition of Multi-Methodological ResourcePlan Evaluation Framework}

The ResourcePlan evaluation framework is a multi-methodological procedure with various instruments. Some of them can be applied chronologically; others, additively. It is being designed for the resource efficiency evaluation of the sector's water (storm- and wastewater), building materials, energy, and land.

In line with the two-step approach of the ResourcePlan (Section 3.1), the developed evaluation framework must be modularly applicable to the processing steps in the two phases. On the one hand, it must contain options to implement the neighborhood's drivers and needs, identify deficits and potential areas, and define solution strategies as well as planning goals. On the other hand, it should be applicable for inter-disciplinary decision making and success control.

The multi-methodological structure of the framework allows a targeted combination of existing and newly developed, innovative methods. To save human resources and avoid additional municipal work (Section 2.1.2), the framework uses existing and wellknown evaluation routines and instruments whenever possible. Other aspects require the development of new approaches.

Figure 5 provides an overview of the resulting ResourcePlan evaluation framework and its main conceptual components. Based on the model of sustainability with its three pillars, Ecological-Social-Economic $[14,15]$, the ResourcePlan evaluation framework leads to three fundamental targets (1-3), represented by the different colors within Figure 5:

1. (Eco)system Services: good ecological conditions, resilient systems, high livability at a local (neighborhood) scale;

2. Life Cycle Assessment: low environmental and human health impacts of the applied technologies on global scale;

3. Economy: economic efficiency and transparency.

On this basis, four supporting elements (I-IV) are defined, represented by the pillars within Figure 5:

I. Systemic-sectoral analysis: sectoral analysis in the neighborhood;

II. Functional-local analysis: merging evaluation on local scale;

III. Life Cycle Assessment: low environmental and human health impacts on a global scale;

IV. Economic Assessment: economic efficiency and transparency.

Elements I and II are inter-connected, both considering (eco)system services. The element focuses on ecosystem services in accordance to [4]. Therefore, ecological as well as social aspects are considered. Since the approach also reflects on system services apart from [4] - e.g., material intensity, greenhouse gas emissions - the element is called (eco)system services. With the systemic-sectoral consideration, it is guaranteed that sectoral system services that are not locally bound are considered. With the local-functional view, local services of the resource land are analyzed and assessed in relation to the resource efficiency of all other neighborhood sectors. In contrast, Elements III and IV are integrated into the structure as independent evaluation components.

Each element results in a partial efficiency, generates target values, is interwoven in their synthesis, and thus determines the operationalization. This structure ensures that the ResourcePlan helps planners to achieve a high level of functionality within a neighborhood without disregarding global environmental goals. 


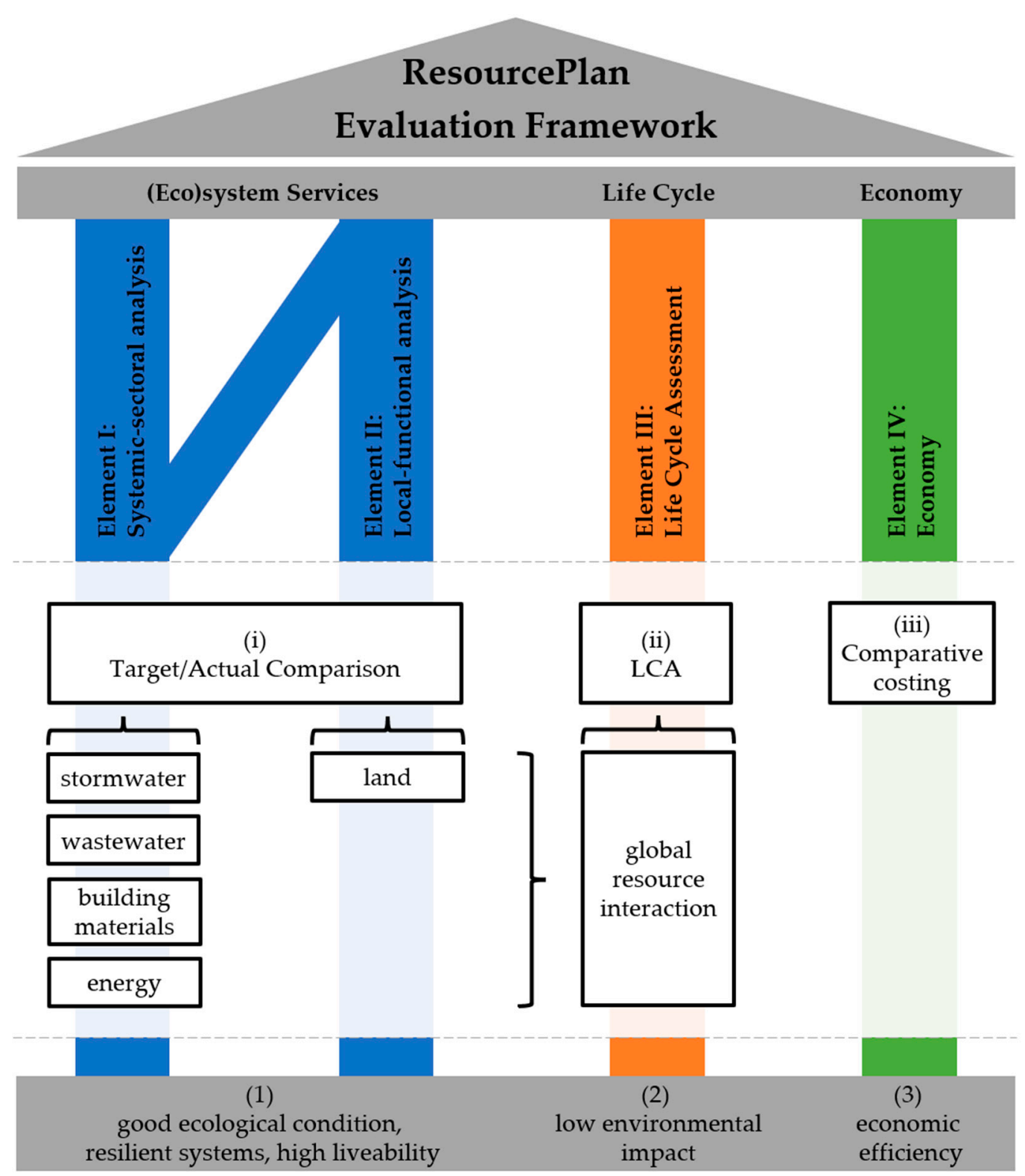

Figure 5. ResourcePlan evaluation framework and its main conceptual components.

Different methods are used for evaluation of the three elements (Figure 5, white boxes). They can be defined as follows:

i. Target/actual comparison for systemic-sectoral analysis (Element I) and local-functional analysis (Element II): The evaluation of (eco)system services is split into the two elements systemic-sectoral analysis (Element I) and local-functional analysis (Element II). The systemic-sectoral analysis is performed individually for water (storm- and wastewater), building materials, and energy. The local-functional analysis is the merging analysis projected onto the resource land (Figure 5). All five evaluation procedures are based on the same evaluation method-the "target/actual comparison". The method can be used both in the set up (Phase I) and the implementation (Phase II) of the ResourcePlan. Figure 6 summarizes the target/actual comparison as a three-step process. The first step (1) aims to derive the TARGET function. The basis for the basic needs in a neighborhood are the concerns of urban land use planning, which are defined in $\S 1$ BauGB, paragraph 6 [37]. They can be formulated as tasks-such as securing space and areas for housing, recreation, transport, or water for irrigation, waste disposal, 
etc.-but also responses to trends-such as climate change and species extinction and much more. For target/actual comparison, these basic services and trends are defined as drivers. In addition, site-specific drivers in the neighborhoods are considered, which are not always transferable to other municipalities. From the drivers, the transformation goals, which determine the requirements for the use of resources in a neighborhood, can be derived, such as climate protection, climate adaptation, health protection, nature conservation, preservation, and further development of the basic functions of existence. The goals can be achieved with a certain use of resources, called TARGET functions. The second step (2) analyzes the actual state. According to the TARGET values, ACTUAL values in the neighborhood are surveyed on a sectoral basis. For this purpose, availability, location of availability, and type/properties of the resource at hand are surveyed to determine the functions that the resource assumes in the ACTUAL state. The third step (3) concludes to derive planning goals. To identify the neighborhood's deficits, TARGET and ACTUAL values are compared based on indicators. For this reason, conflicting targets may arise for different indicators. The conflicting goals must be weighed individually according to the above-mentioned needs of the neighborhood.

(1) TARGET FUNCTION

\begin{tabular}{|c|c|}
\hline Drivers & $\begin{array}{c}\text { Transformation } \\
\text { goals } \\
\text { basic functions of } \\
\text { existence, } \\
\text { global trend, } \\
\text { defined based on } \\
\text { drivers }\end{array}$ \\
\hline
\end{tabular}

survey from global to local level
(3) COMPARISON

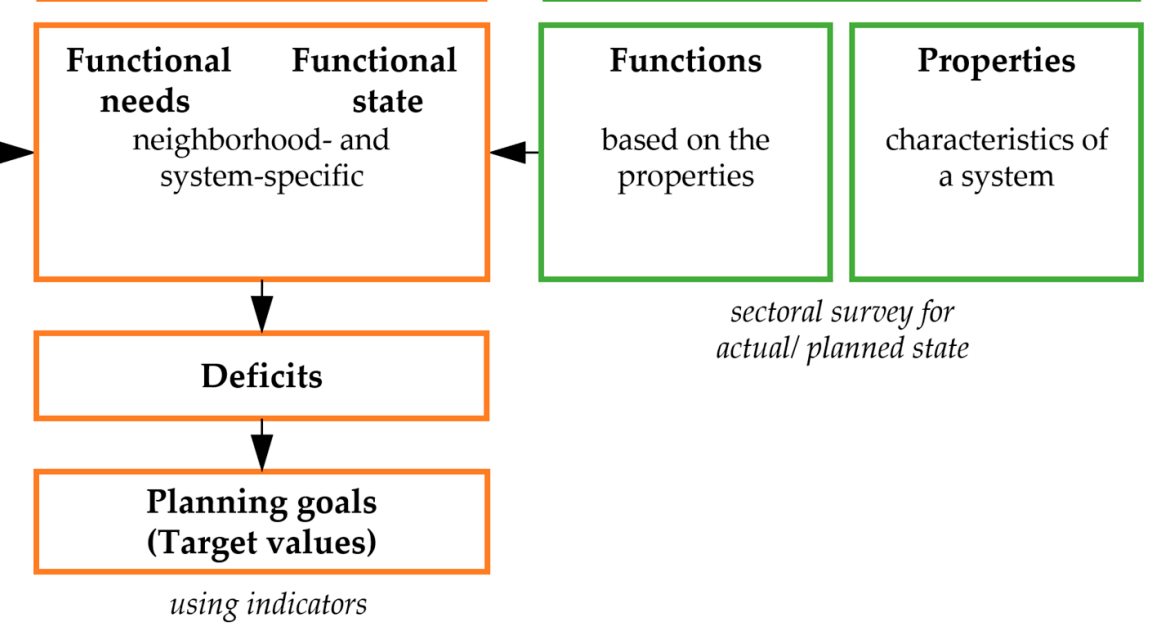

(2) ACTUAL STATE 
expenditures related to the ACTUAL state in relation to the potential outcome are compared and have to be evaluated regarding the available budget of the commune. Both investment and operating costs should be considered using comparative costing methods such as the dynamic cost comparison calculation provided by [93]. The results are not convertible from municipality to municipality due to regional differences of costs and ownership structures.

\subsubsection{Element-Specific Evaluation Procedures and Synthesis}

To integrate the evaluation framework into the municipal structures, work steps, outputs, and their synthesis must be defined. The procedure consists of the methods described in the previous section, which are transferred to the sectoral procedures modularly.

The following section will summarize the element-specific evaluation procedures, their outputs, and their synthesis. An overview is given in Figure 7. Process steps are marked with capital letters $(\mathrm{A}-\mathrm{H})$, while their outputs and linkages are marked with small letters $(\mathrm{a}-\mathrm{i})$.

(A) Driver analysis: According to Section 3.3.1, a driver analysis must be carried out to identify all needs of the neighborhood for all disciplines and from a global to a location-specific level. Global drivers can be identified according to scientific findings on the basic functions of existence and the global trends (e.g., climate change). Additionally, several methods are possible for recording the location-specific drivers. These include the evaluation of informal conversations, for example, in the context of a World Café event, a guideline-based, internal administrative survey, a neighborhood survey, and, above all, the analysis of strategy papers and concepts that contain the transformation goals at both federal and municipal level. The drivers can be transferred to transformation goals and neighborhood-specific target functions.

(a) Transferring target functions to target/actual comparison: The target functions identified in (A) are transferred to the target/actual comparisons. Sectoral target functions $\left(\mathrm{a}_{1}\right)$ are transferred to the systemic-sectoral analysis (B), while all other area-related target functions $\left(\mathrm{a}_{2}\right)$ enter the location-functional analysis $(\mathrm{C})$.

(B) Systemic-sectoral analysis: The target/actual comparison is adapted for the sectoral evaluation of resource efficiency of the sectors water (storm- and wastewater), building materials, and energy. An extension of the approach to include additional sectors or further systemic considerations (e.g., mobility) is possible.

The systems are considered within the spatial boundaries of the sectoral-defined neighborhood (Section 2.2.1). This means, that all system-relevant infrastructures can be considered, although they are outside the control space (e.g., wastewater treatment plant, wind power). Internal and external interactions can thus be integrated according to requirements.

The target/actual comparison is carried out on an indicator basis using sectoral methods and instruments. Table 2 summarizes these main findings on the systemicsectoral analysis. Drivers and transformation goals are aligned to national and international objectives as well as current scientific knowledge. If possible, existing, widely distributed methods and instruments are used for analysis to minimize additional effort (storm- and wastewater). If not, the required instruments are developed within the project (building materials and energy). Further details on the systemic-sectoral analysis will be published in subsequent research. 

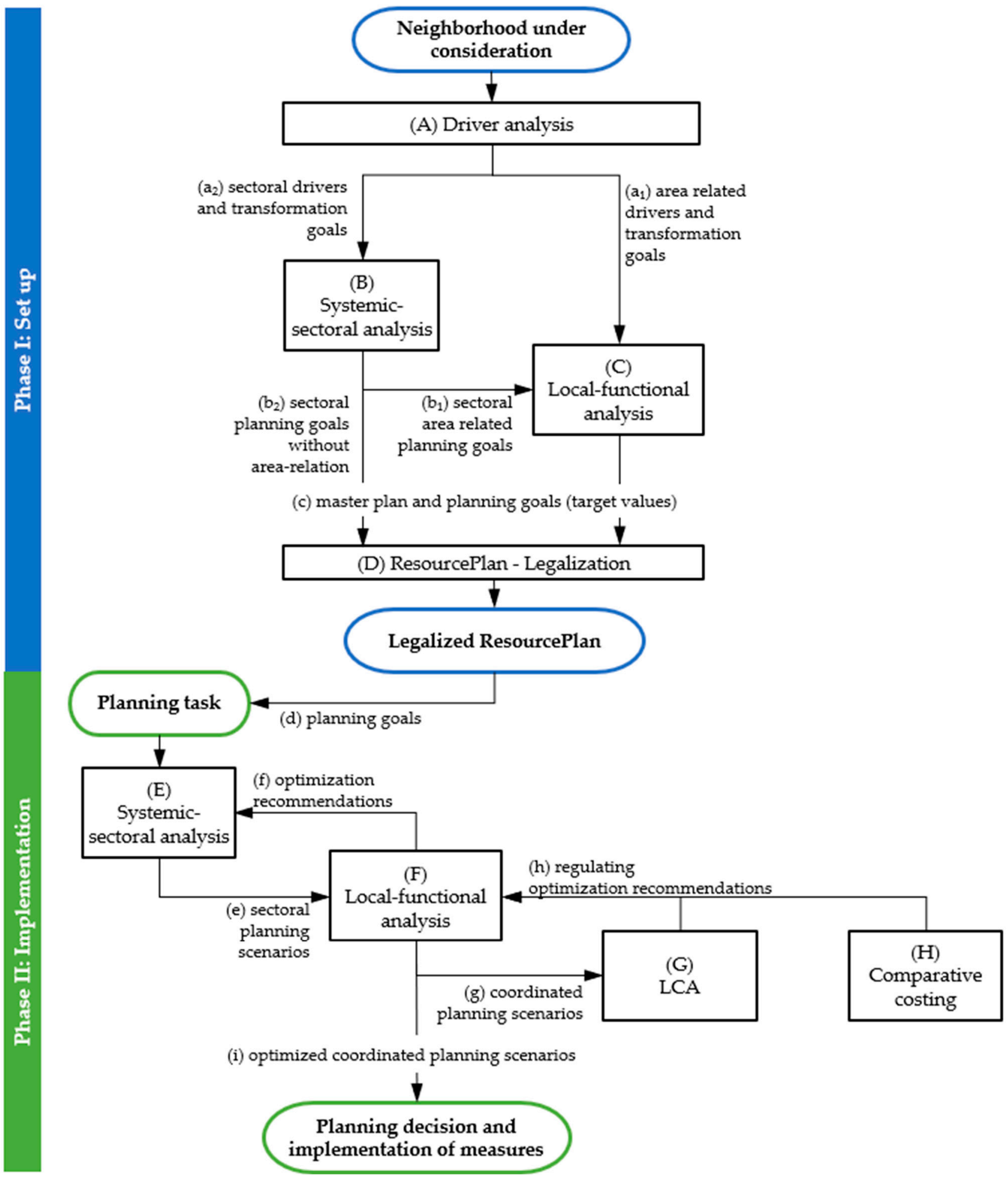

Figure 7. Flowchart of evaluation procedure. 
Table 2. Overview on target/actual comparison of systemic-sectoral analysis.

\begin{tabular}{|c|c|c|c|c|c|}
\hline Sector & Driver & $\begin{array}{l}\text { Transformation } \\
\text { Goal }\end{array}$ & $\begin{array}{l}\text { Exemplary } \\
\text { Indicators }\end{array}$ & Methods/Instruments & $\begin{array}{l}\text { Exemplary } \\
\text { Planning Goals }\end{array}$ \\
\hline stormwater & $\begin{array}{l}\text { water body } \\
\text { pollution control; } \\
\text { disposal safety; } \\
\text { safety in use; } \\
\text { resource } \\
\text { protection; } \\
\text { national and } \\
\text { inter-national } \\
\text { climate } \\
\text { protection goals }\end{array}$ & $\begin{array}{l}\text { preservation of } \\
\text { natural water } \\
\text { balance; } \\
\text { pollution control; } \\
\text { flood prevention; } \\
\text { evaporative } \\
\text { cooling } \\
{[24,26,94]}\end{array}$ & $\begin{array}{l}\text { water balance; } \\
\text { emissions of total } \\
\text { suspended solids, } \\
\text { heavy metals, } \\
\text { nutrients, or } \\
\text { biocides; } \\
\text { flood risk; } \\
\text { evapotranspiration }\end{array}$ & $\begin{array}{l}\text { rainfall } \\
\text { runoff-modeling; } \\
\text { water balancing; } \\
\text { flood modeling } \\
{[95,96]}\end{array}$ & $\begin{array}{l}\text { degree of sealing; } \\
\text { degree of drainage } \\
\text { area; } \\
\text { recommended } \\
\text { measures; } \\
\text { ban on } \\
\text { water-polluting } \\
\text { materials; } \\
\text { degree of urban } \\
\text { green }\end{array}$ \\
\hline wastewater & $\begin{array}{l}\text { water body } \\
\text { pollution control; } \\
\text { disposal safety; } \\
\text { safety in use; } \\
\text { resource } \\
\text { protection; } \\
\text { national and } \\
\text { international } \\
\text { climate } \\
\text { protection goals }\end{array}$ & $\begin{array}{l}\text { water recovery; } \\
\text { nutrient recovery; } \\
\text { pollution control; } \\
\text { minimization of } \\
\text { greenhouse gas } \\
\text { emissions; } \\
\text { primary and end } \\
\text { energy demand } \\
{[24,97]}\end{array}$ & $\begin{array}{l}\text { drinking water } \\
\text { demand; } \\
\text { resource recovery } \\
\text { of nitrogen and } \\
\text { phosphorus; } \\
\text { emissions of COD, } \\
\text { nitrogen, and } \\
\text { phosphorus; } \\
\text { end energy } \\
\text { demand; } \\
\text { greenhouse gas } \\
\text { emissions }\end{array}$ & $\begin{array}{l}\text { material flow analysis; } \\
\text { life cycle assessment; } \\
\text { life cycle costing } \\
\text { [98] }\end{array}$ & $\begin{array}{l}\text { degree of resource } \\
\text { recovery (heat, } \\
\text { nitrogen, } \\
\text { phosphorus, } \\
\text { water) }\end{array}$ \\
\hline $\begin{array}{l}\text { building } \\
\text { materials }\end{array}$ & $\begin{array}{l}\text { shortage of raw } \\
\text { materials; } \\
\text { resource } \\
\text { protection; } \\
\text { conserving } \\
\text { natural resources; } \\
\text { safety in use; } \\
\text { security of } \\
\text { supply }\end{array}$ & $\begin{array}{l}\text { mapping of the } \\
\text { anthropogenic } \\
\text { stock; } \\
\text { reuse; } \\
\text { closed loops of } \\
\text { building } \\
\text { materials }\end{array}$ & $\begin{array}{l}\text { material intensity; } \\
\text { recycling rate; } \\
\text { reuse rate; } \\
\text { take-back systems; } \\
\text { pollutant fraction }\end{array}$ & $\begin{array}{l}\text { object modeling; } \\
\text { material allocation; } \\
\text { aging models and } \\
\text { usage predictions }\end{array}$ & $\begin{array}{l}\text { improve data; } \\
\text { recommended } \\
\text { measures; } \\
\text { identification of } \\
\text { recycling } \\
\text { potentials }\end{array}$ \\
\hline energy & $\begin{array}{l}\text { national and } \\
\text { international } \\
\text { climate } \\
\text { protection goals; } \\
\text { demand for } \\
\text { low-cost energy } \\
\text { supply; } \\
\text { conservation of } \\
\text { fossil fuels; } \\
\text { increase in } \\
\text { regional value } \\
\text { added [99-101] }\end{array}$ & $\begin{array}{l}\text { minimization of } \\
\text { greenhouse gas } \\
\text { emissions; } \\
\text { increase of } \\
\text { renewable } \\
\text { energies; } \\
\text { minimization of } \\
\text { system costs; } \\
\text { minimization of } \\
\text { final energy } \\
\text { consumption } \\
\text { [83] }\end{array}$ & $\begin{array}{l}\text { greenhouse gas } \\
\text { emissions; } \\
\text { energy costs; } \\
\text { final energy } \\
\text { demand } \\
\text { [83] }\end{array}$ & $\begin{array}{l}\text { energy system } \\
\text { modeling and } \\
\text { optimization [102] }\end{array}$ & $\begin{array}{l}\text { minimization of } \\
\text { the applied } \\
\text { indicators }\end{array}$ \\
\hline
\end{tabular}

(b) Sectoral planning goals and solution strategies: Systemic-sectoral evaluation procedures provide planning goals for all sectors. The area-related planning goals as well as best-fit solution strategies $\left(b_{1}\right)$ are included in the local-function analysis $(C)$ as transformation goals. These solution strategies mark deficit and potential areas for transformation as well as recommended solutions (e.g., measures). Planning goals without an area reference $\left(b_{2}\right)$ are transferred directly to the ResourcePlan.

(C) Local-functional analysis: The local-functional analysis is designed to synthesize the sectoral planning goals $\left(\mathrm{a}_{1}\right)$ and to evaluate the neighborhood's resource efficiency holistically. The approach evaluates resource efficiency on an aerial basis. With reference to the definition of resource efficiency and the term "benefit" (Section 2.2.3), benefit presup- 
poses a function of a thing, for which there is a need, as well as its commissioning. At the same time, the efficient use of the land assumes a high functionality, i.e., a high number of functions. This means that land is used efficiently if it has as many functions as possible for which there is a need. The goal of the entire process is called benefit creation.

The increase in functionality is achieved by changing its properties. The functions are derived geodata-based. The conceptual approach is shown in Figure 8. Geodata-based properties are aggregated to functions following defined rules. Referring to the drivers identified in (A), evaluations on the fulfilment of the transformation goals can be performed by assigning the functions to transformation goals. Detailed information will be given in subsequent research.

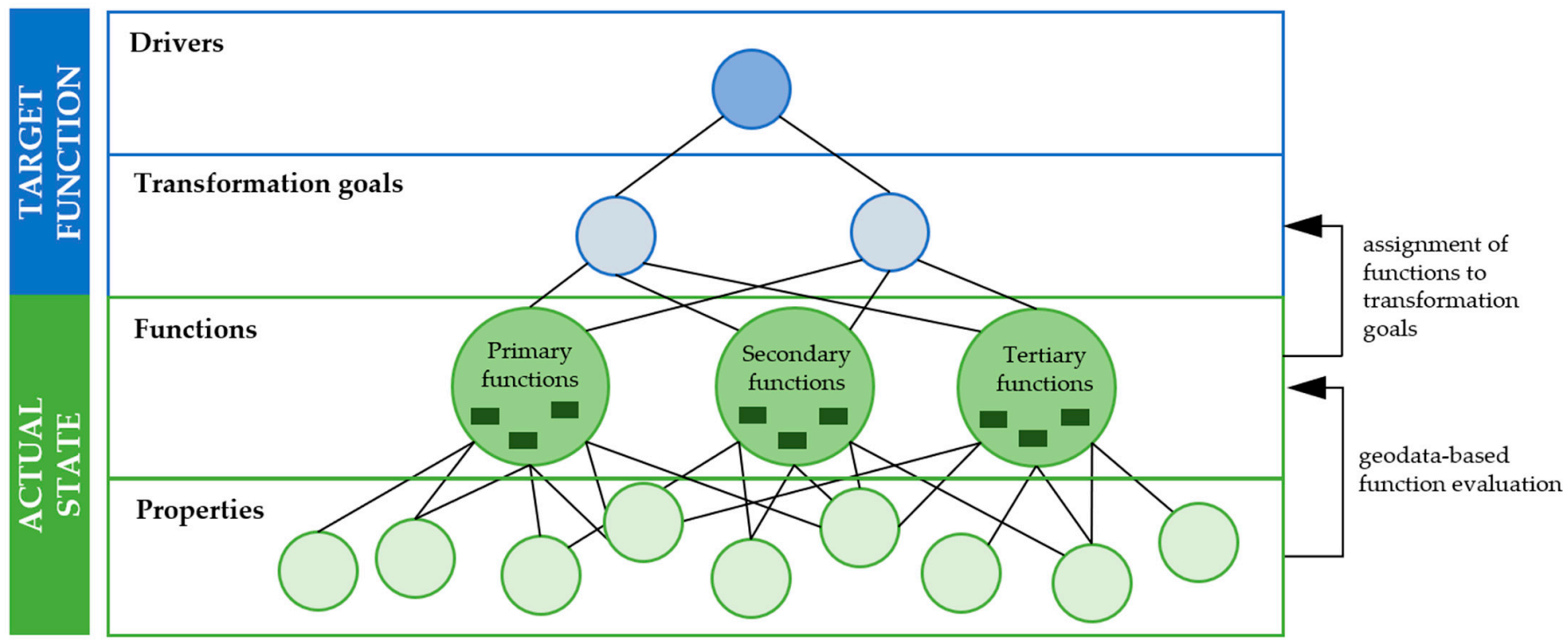

Figure 8. Conceptual approach to derive an area's functionality in a local-functional analysis.

The functions of an area are differentiated into three types. Firstly, it has primary functions, which are defined as equivalent to the basic existence functions (e.g., housing, transport, work). Secondly, areas often have unintended functions, called secondary functions. Secondary functions are considered here to include regulating, productive, and supporting ecosystem services, both negative and positive (e.g., groundwater recharge, flood prevention, biodiversity, cooling at daytime or heat loading, pollutant source). Thirdly, functions, which were not intended when the area was designed, are called tertiary functions. They arise through the active appropriation of an actor or-apart from their actual purpose-through anthropogenic benefit, e.g., cultural ecosystem services.

(c) Coordinated master plan and planning goals (target values): The developed sectoral solution strategies are summarized and checked for conflicting goals using the local-sectoral analysis. The local-functional analysis identifies areas where transformative measures are needed and supports decision making in allocating measures for water, energy, or land use purposes. If contradictions in between the sectoral solution strategies arise, they must be weighed up in an inter-disciplinary discussion. Finally, all findings are summarized to one master plan. Area related planning goals $\left(b_{1}\right)$ are checked and optimized for conflicting goals as well. All findings together-master plan and planning goals-are transferred for ResourcePlan legalization (D).

(D) ResourcePlan-Legalization: The ResourcePlan is established within the municipality's formal and informal instruments according to Section 3.2.2.

- End of Phase I-The ResourcePlan is set up.

- Beginning of Phase II-A new planning task has come up.

(d) Planning goals: For new planning tasks, the planning goals out of the ResourcePlan are set as the target value for further evaluations. 
(E) Systemic-sectoral analysis and (e) Sectoral planning scenarios: Sectoral planning scenarios are set up using systemic-sectoral analysis according to (B). The scenarios are transferred to local-functional analysis $(\mathrm{F})$

(F) Local-functional analysis: All sectoral planning scenarios are summarized using local-functional analysis according to (C).

(f) Optimization recommendations: Output of the local-functional analysis are optimization recommendations for the sectoral planning scenarios. These are generated in the local-functional analysis by identifying conflicting goals or more appropriate areas with greater potential for transformation to allocate action. The recommendations enter a recursive optimization process of systemic-sectoral and local-functional analysis.

$(g)$ Coordinated planning scenarios: After optimizing the scenarios in the recursive process of systemic-sectoral and local-functional analysis, a coordinated planning scenario is generated and transferred to evaluations of life cycle assessment $(G)$ and comparative costing $(\mathrm{H})$.

$(G)$ Life Cycle Assessment and $(H)$ Comparative Costing: Decision support is provided by LCA $(\mathrm{G})$, the life cycle assessment, which is used to compare measures that can contribute (along their supply chain) to global environmental impacts. This aims to ensure that high resource efficiency and use density are not realized locally at the price of increased global environmental impacts. In order to make the results interpretable for non-LCA experts, the ecological impacts are monetized with the help of the German Federal Environment Agency's cost factors [92]. Finally, the ownership conditions of the resource and its existing or new use influence the scope for transformation. Comparative costing $(\mathrm{H})$ can further facilitate the decision on which transformation to implement by providing some economic aspects, such as investment and maintenance costs.

(h) Regulating optimization recommendations: Regulating optimization recommendations of $(\mathrm{G})$ and $(\mathrm{H})$ are integrated into final optimization and decision making.

(i) Optimized coordinated planning scenarios: Finally, for optimized planning scenarios for all sectors, their synthesis are fixed and can be transferred to the ResourcePlan and its legalization process $(\mathrm{F})$.

\subsection{Exemplary Case Study}

The following section aims to illustrate the findings described above by means of a case study (Section 2.3). To avoid complexity, only the sectoral analysis of stormwater is shown exemplary. Evaluations on the other sectors are carried out equivalent to the procedure presented in the following. Further details on the systemic-sectoral analysis will be published in subsequent research. The case study is divided into the two stages according to Figure 4, (i) set up and (ii) implementation of the ResourcePlan.

\subsubsection{ResourcePlan Set Up (Phase I)}

To set up the ResourcePlan, the neighborhood is examined with the systemic-sectoral analysis as well as the local-functional analysis of the resource area. Table 3 summarizes the main findings of the two investigations. The results are structured in accordance with the interim result steps A to E, defined in Section 3.1. 
Table 3. Interim results of systemic-sectoral and local-functional analysis for setting up the ResourcePlan. $\mathrm{A}=$ drivers and needs; $\mathrm{B}=$ transformation goals; $\mathrm{C}=$ deficit and potential areas; $\mathrm{D}=$ solution strategies; $\mathrm{E}=$ planning goals.

\begin{tabular}{|c|c|c|}
\hline Step & $\begin{array}{l}\text { Systemic-Sectoral Analysis } \\
\text { (Exemplary Stormwater) }\end{array}$ & Local-Functional Analysis \\
\hline A & see Table 2 & $\begin{array}{l}\text { climate change } \\
\text { need for garden space }\end{array}$ \\
\hline B & see Table 2 & $\begin{array}{c}\text { climate adaptation, health protection, } \\
\text { nature conservation, basic function } \\
\text { recreation/recreation }\end{array}$ \\
\hline $\mathrm{C}$ & $\begin{array}{l}\text { no further flood risk, deficits at water balance, exceeded } \\
\text { emissions from high frequented roads }\end{array}$ & $\begin{array}{l}\text { deficit: sealed areas/traffic areas, } \\
\text { potential: greened areas }\end{array}$ \\
\hline $\mathrm{D}$ & $\begin{array}{l}\text { best fit scenario including coupling of green roofs, } \\
\text { infiltration, intensified greening, rainwater harvesting, } \\
\text { centralized treatment, and permeable pavements. }\end{array}$ & transformation of surface design \\
\hline $\mathrm{E}$ & $\begin{array}{l}\text { degree of sealing as proportion of the } \\
\text { currently sealed area, } \\
\text { degree of drainage area as a proportion } \\
\text { of current drainage area }\end{array}$ & $\begin{array}{l}\text { transformation potential of primary, } \\
\text { secondary, and tertiary functions }\end{array}$ \\
\hline
\end{tabular}

Driver analysis: As a first step for setting up the ResourcePlan, a global and locationspecific driver analysis according to Section 3.3.2, step (A), is carried out. In Herne, global drivers have been transferred to informal instruments such as the climate adaptation concept. In the neighborhood under consideration, actions for eliminating urban heat islands are needed. In addition, there is a citizens' initiative for biodiversity and garden spaces. Therefore, the fundamental global drivers and transformation goals are:

- Climate change - transformation goal: climate adaptation/elimination of heat islands;

- Need for garden space-transformation goal: biodiversity, health protection, nature conservation, basic function recreation/recreation.

Systemic-sectoral analysis: As a second step for setting up the ResourcePlan, systemicsectoral analyses are carried out. Sectoral drivers (A) and transformation goals (B) are given in Table 2. The analysis of deficits (C) is conducted for the three indicators flood risk, water balance, and emissions. The flood risk analysis does not identify any further risk for the parking lot. From this view, no transformation need can be identified. The water balance analysis is performed according to Henrichs et al. [95]. For the neighborhood under consideration, it shows absolute deviations between the actual and pre-developed state of $+20 \%$ for runoff, $-3 \%$ for groundwater recharge and $-16 \%$ for evapotranspiration. Therefore, groundwater recharge and evapotranspiration must be supported, while runoff should be reduced. Options are a reduction of soil sealing and/or the allocation of decentralized blue-green infrastructures. Evaluations on emissions show exceeded total suspended solids as well as heavy metal, nutrient, and biocide. The most influential areas for emissions are the highly frequented roads "Westring" and "Bahnhofstraße". The solution strategy (D) includes a coupling of green roofs, infiltration, intensified greening, rainwater harvesting, decentralized treatment, and permeable pavements. The planning goals for later success control (E) are formulated as target values for degree of sealing and degree of drainage area. The goal for the degree of sealing is derived from the deficits of the water balance. The degree of drainage area goes back to the emissions.

Local-functional analysis: As a third step for setting up the ResourcePlan, the local functional analysis is carried out. Drivers (A) and transformation goals (B) are mentioned above. The areas of the neighborhood have different characteristics and thus functions that are conducive to the above-mentioned transformation goals to varying degrees. Figure 9 shows the results of local-functional analysis for transformation goal "climate adaption" exemplarily. Deficits can be identified on the sealed surfaces. While there is a high degree 
of positive effects on the transformation goal of climate adaptation in the areas of gardens, traffic areas, with their high heat absorption and surface runoff, have many negative effects (C). Depending on the type of use (type of traffic, type of traffic route), transformations of the surface design in favor of functions with positive effects are possible. Sealed surfaces whose primary functions are no longer needed to a sufficient extent have a particularly high potential for adding positive effects to the transformation goal of climate adaptation. Increasing functionality corresponds to solution strategy (D). The planning objectives (E) are defined in terms of the transformation potential of primary, secondary, and tertiary functions of the areas.

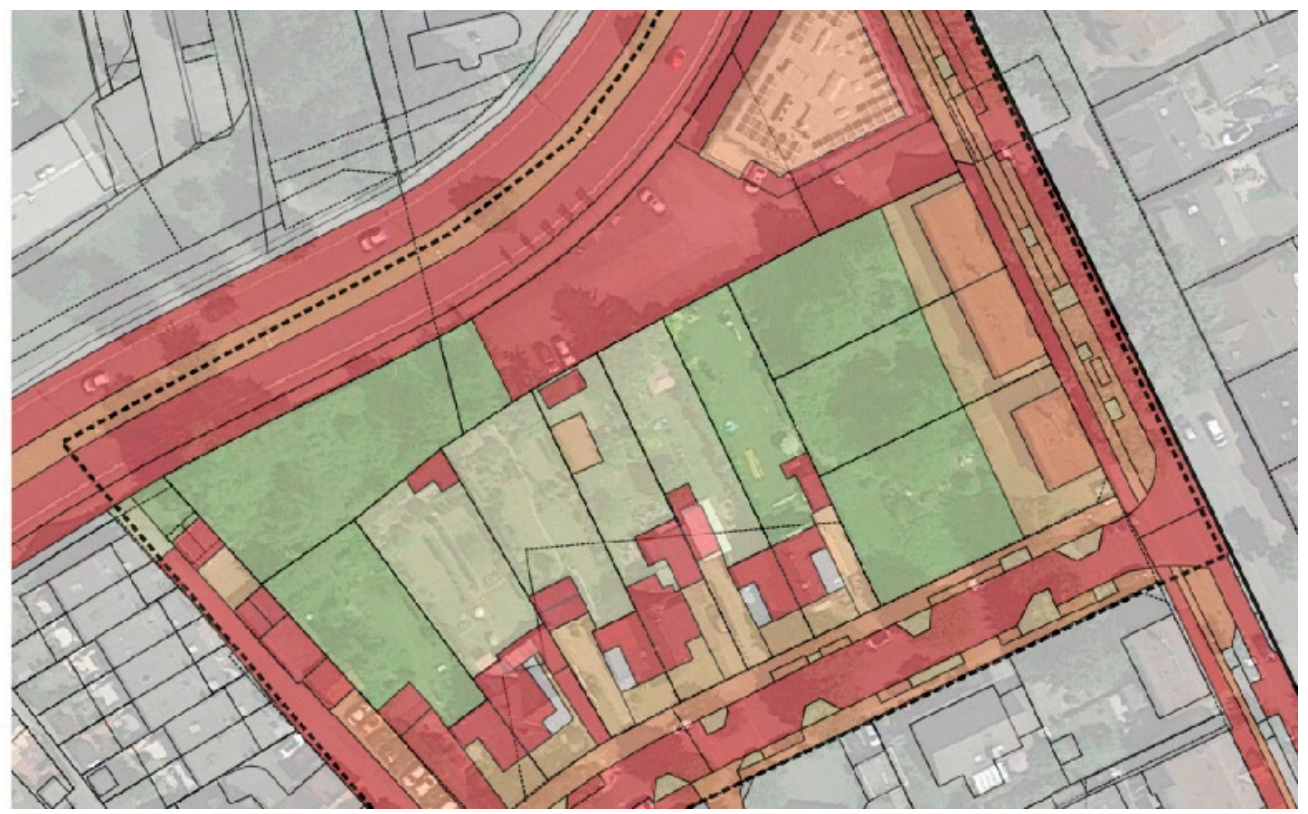

Figure 9. Results of local-functional analysis for transformation goal "climate adaption".

Set up ResourcePlan: The solution strategies and planning goals of the various analysis are summarized and checked for conflicting goals and feasibility. No contradictions arise in the present example. Masterplan and planning goals can be legalized according to the options of integration into municipal structures described in Section 3.2.2.

\subsubsection{ResourcePlan Implementation and Decision Making (Phase II)}

The ResourcePlan as set up (Section 3.4.1) includes transformation recommendations as well as planning goals. Deficits around the business building in the north of the subneighborhood (Figure 9) have been identified. Therefore, the parking lot (blue mark in Figure 3) should be transformed. It is $800 \mathrm{sqm}$ in size, has a compact geometry, and is conveniently located on a highly frequented road and near a park. The area is in public ownership. It is asphalted, has no planting and the asphalt surface is in poor condition. The area has conversion potential, as it develops severe heat stress in hot summers. The parking lot has only a moderately low occupancy rate. It is often empty, especially on weekends. The following considerations are made during decision making:

Systemic-sectoral analysis: To optimize stormwater management, it is recommended to plant trees at the edge of the parking lot in accordance with step D in Table 3. The trees increase evapotranspiration. Runoff from the parking lot can be incorporated into decentralized infiltration systems. This leads to an increase of groundwater recharge and evapotranspiration. Permeable pavements are recommended, as well. The water balance moves closer to its natural state. Due to its moderately low occupancy rate, no treatment is needed for this parking lot. 
Local-functional analysis: Local-functional analysis combines sectoral planning scenarios for decision making. Exemplary results for functionality evaluation for three different scenarios are shown in Figure 10.

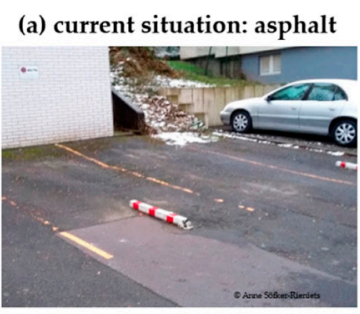

(i) Primary function: Parking lot

(ii) Secondary function: evapotranspiration

groundwater recharge,

retention,

flood prevention,

biodiversity,

cooling at daytime,

pollutant source (TSS,

heavy metals,

nutrients, or biocides)

(iii) Tertiary function:

children's playground
0 points

8 points
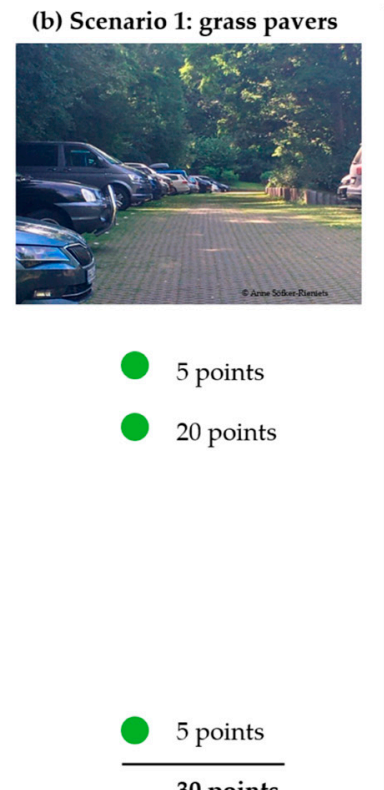

30 points (c) Scenario 2: allotments

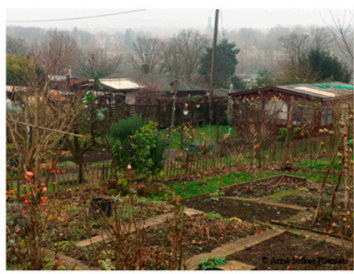

5 points

40 points

5 points

50 points

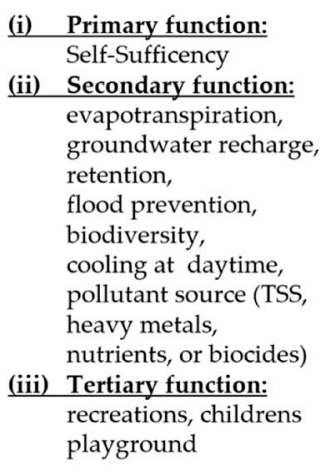

Secondary function: potranspiration, water recharge, cooling at daytime, heavy metals, nutrients, or biocides) playground

Figure 10. Functionality evaluation of the considered parking lot showing three different scenarios: (a) current situation-asphalt, (b) scenario 1-grass pavers, (c) scenario 2-allotments.

At current state (Figure 10a), the primary function of this space is vehicular access. The fulfilment of the primary function is fully met in this area, because its characteristics fulfil the need for trafficability and drainage according to the current state of the art. The parking lot also has secondary functions, for example, pollutant source, surface runoff, etc., which only have negative effects on the above-mentioned transformation goals (e.g., intensification of heat islands). The possible tertiary functions here are children playing on the surface. Due to low points at secondary functions, the current state is only scored with 8 points.

The evaluation leads to a need for transforming the surface condition of this parking lot. With open laid slabs or grass pavers (Figure 10b), it would be possible to support the goal of eliminating heat islands or climate adaptation with higher functionality at groundwater recharge, evapotranspiration, or biodiversity. To ensure that the parking lot is also used enough at weekends, it could be a good idea to maintain easily passable strips for a traffic course where children can practice cycling in traffic. All in all, the surface transformation would lead to a functionality score of 30 .

Alternatively, it would be possible to undertake a transformation of the primary function, abandon the parking lot, and convert it into allotments (Figure 10c). While being used for self-sufficiency and recreation as primary function, its secondary functions would be several regulating, supporting, and providing ecosystem services such as groundwater recharge, cooling, animal and plant habitats, and many more. The area would be scored with 50 points. Whether the missing parking space would cause problems must be considered by comparing the parking requirements.

The functionality analysis shows different results for the three scenarios. Which option is chosen always needs to be decided in the whole neighborhood's context. The following assessments of life cycle and economy could help at further decision making.

Life Cycle Assessment: In relation to the parking lot, LCA can compare different types of paving stones and provide information on which have the lowest embedded $\mathrm{CO}_{2}$ emissions and other environmental impacts. E.g., the use of natural stone would be preferable to the use of concrete, as concrete has high $\mathrm{CO}_{2}$ emissions in the production as long as 
the overall amount is similar. Furthermore, the use of local materials is preferred as the transport distance is decisive for the embedded emissions of construction materials. As most transport is fossil fuel-based and produces local air pollution, transport distances should be minimized. For the allotments, it can provide guidance on which building materials should be preferred for the gardens, e.g., locally sourced timber or recycled materials (e.g., concrete) and under what conditions. Additionally, for houses with only one floor (which are mostly used in allotment gardens) the construction with natural materials such as clay, wood, and natural stone is feasible and a real alternative to concrete.

Economy: The economic characteristics of the parking lot compared to the allotment garden site depend on the economic relations and regulations in a particular country or region. The parking lot could be owned by a private company or by the city. If it is owned by the city, the city receives revenue from the residents but also has to pay for the maintenance. Usually, the maintenance costs far exceed the revenue. However, since the parking lot already exists, there are no investment costs. In Herne in Germany, the annual maintenance costs far exceed the fees paid by the residents so that the balance of running costs would be negative. For the allotment gardens, it would first be necessary to unseal the area of the parking lot and find tenants. Once the allotment site is established, it would also generate an income stream from leasing-but since the people who own the gardens have to look after them, there would be no additional cost to the local government. Thus, some investment costs would be required, but the running costs would be positive. Of course, this model—as well as the park model—would only be applicable if there is the appropriate demand for these uses.

Final decision: Various evaluations have been carried out while decision making with considering the recommendations and planning goals of the ResourcePlan. The results show that the different evaluation elements can generate indications for integrated decision making. Based on the previously identified needs and planning goals, resource efficiency can be considered in terms of sectoral and local-functional impact. LCA and comparative costing have a regulating effect on decision making. The final decision must be made in inter-disciplinary exchange.

\section{Discussion}

The developed instrument ResourcePlan integrates resource protection as a legal instrument bindingly into the municipal practice and supports integrated strategies and decisions for the resource-efficient development of urban neighborhoods as a planning instrument.

The concept development as well as the first applications highlight integrative action at all administrative levels as a key factor for successful resource management. However, successful implementation is very complex, requiring a high degree of coordination and consistency (Section 3.2.1). The demands of resource management in terms of content and law must be systematically operationalized in municipal action. This can be achieved if the obligation to manage resources is anchored at the highest legal level and is concretized at the lowest level through framework plans and recommendations for measures.

As a municipal control instrument, the ResourcePlan can significantly increase the transparency, enforceability, and binding nature of resource-relevant planning decisions and thus creates short- and long-term liabilities. In regard to $[40,41,68]$, this would provide further assertiveness in the ambivalence of the political discourse and conflicting goals. Additionally, implementation obstacles due to missing liability and transparency, such as those mentioned by [73-75], are reduced. Implementing the ResourcePlan as a package of instruments (Section 3.2.2) provides great flexibility, since the instruments can be individually adapted to specific municipal needs. Instead of having to develop a one-fits-all instrument, the regulations can be implemented within existing structures, corresponding to the different ownerships (private/public areas) and life cycle of urban structures (new construction/existing buildings). Additionally, sectoral aspects might be established more efficiently in the sectoral framework plans (e.g., wastewater disposal concept). 
On the one hand, this decentralized practice avoids additional legal levels within municipal legal structures but rather integrates the requirements into the existing instruments. Therefore, regulations can be implemented in a more targeted manner with a higher level of legal certainty. On the other hand, the decentralized approach is more complex and less manageable. The effort for coordinating the integration in various individual instruments is higher. In addition, updating the formal and informal instruments cannot always be carried out flexibly timed. The already implemented regulations must be checked regularly for actuality and adjusted if necessary. Ongoing inter-disciplinary cooperation beyond the individual departments must be ensured. Thus, the long-term practicability of the proposed structures of the ResourcePlan as a package of instruments still needs to be tested. Although the instrument was developed and evaluated in discussion with stakeholders from the municipalities, the actual implementation and transfer to other neighborhoods will offer the opportunity to further evaluate and optimize the structure of the legal instrument.

The developed evaluation framework also allows the ResourcePlan to be used as a synoptic planning tool for optimizing resource efficiency. (Eco-)system performance, global environmental impact, and economic efficiency capture important dimensions of sustainability. In addition to the inter-disciplinary evaluation, sectoral considerations can be introduced into the decision-making process with sufficient technical detail. In contrast to other partial evaluation methods (e.g., [69-72]), the multi-methodological structure therefore allows for needs-oriented application, including global to local as well as intraand inter-disciplinary assessments. The concept is based on national and international targets and current scientific findings. Adaptation to new target values or scientific findings is possible. In addition, extension to other sectors is possible (e.g., air, soil, mobility). This ensures good transferability and long-term use.

The conception of the neighborhood as a control and observation area allows for a highly concrete and binding resource management. In contrast to the large-scale assessment of the entire city or city districts (e.g., [56,57]), the evaluation is based on functional units that form a social and infrastructural entity. The evaluations can therefore be carried out in a much more targeted and needs-oriented manner. At the same time, the definition of the neighborhood boundaries according to the fuzzy concept of Olaf Schnur [76] ensures that the external and internal bonds can be considered according to the individual sectoral requirements. However, the small-scale approach at the neighborhood level can result in a large increase in effort. In addition, for some sectors, the infrastructure systems are usually much larger than the neighborhood (e.g., energy system or drainage system, including wastewater treatment plant). For this reason, it may be appropriate to prepare ResourcePlans for larger spaces at the same time and then downscale to specific needs at the neighborhood level. The practicability of this proposal must be demonstrated in application.

The multi-method structure allows the modules to be applied or updated independently. If some aspects are to be prioritized or other aspects are not relevant in the specific neighborhood context, individual weighting is possible. In contrast, the high degree of modularity also brings the risk of high complexity. Several stakeholders always must be involved. Inter-disciplinary cooperation and discussion are necessary. Due to the high modularity, careful data management is needed for successful application of the ResourcePlan evaluation framework. Geodata-based processing ensures open interfaces and thus high flexibility for handling in terms of time and space. At present, smaller municipalities will still have difficulties in IT implementation, but rapid progress can be expected in this sector. The scope and quality of sectoral data are constantly improving, as are the IT skills of employees, so that even small municipalities will be able to develop solutions soon.

The assessment of resource efficiency in terms of area (local-functional analysis) is innovative and supports the idea of area performance as well as urban ecosystem performance. At the same time, the approach is spatially and temporally independent and updatable as well as freely scalable from the neighborhood to the parcel level. It fills the gap of the missing assessment tools accounting multi-functionality and free scalability, such 
as those stated by [72]. If the tool is updated regularly, many processes can be combined and simplified with a long-term perspective. However, it must be noted that the evaluation framework is not conceptualized for benchmarking. Relative improvements within a neighborhood compared to the previous state can be mapped. However, since needs and target values differ from neighborhood to neighborhood, an absolute comparison of two neighborhoods is not possible.

In summary, the findings from the development and initial application phase allow us to conclude that the ResourcePlan is becoming a suitable tool for making short- and long-term resource management in the neighborhood much easier and more transparent. However, future research must focus on long-term applicability of the proposed instrument. Since the given paper focuses on the theoretical conceptualization and first application of the ResourcePlan, practical evaluation and optimization are pending. In detail, aspects for further consideration are (i) the instrument's complexity (e.g., structure, requirements), (ii) applicability and comprehensibility for planning purposes, (iii) effort and benefit in daily municipal routines, (iv) transferability to other neighborhoods and municipalities, as well as (v) legal assertiveness.

\section{Conclusions}

The ResourcePlan is an instrument for the resource-efficient development of urban neighborhoods. It represents both a legal and a planning instrument that was developed in a transdisciplinary exchange between municipal stakeholders and scientists.

The legal instrument ResourcePlan integrates solution strategies and planning goals into existing formal and informal instruments of municipal action and avoids additional legal levels. In the spatial basis of the neighborhood, a more targeted implementation of locally developed regulations can be achieved with greater legal certainty on the one hand, but also implies a clear mandate for close coordination and continuity on the other hand. In addition, to strengthen enforcement at the municipal level, resource protection must be anchored across all legal levels, as stated in the premises developed for legal integration.

The planning instrument ResourcePlan addresses the increase of resource efficiency at sectoral resource management of (i) water, (ii) building materials, (iii) energy, and (iv) land. The integrated, multi-methodological evaluation framework considers (eco)system services, global environmental impacts, and economic efficiency. According to the two-stage approach-ResourcePlan set up and implementation-the instrument can be used multifunctionally in the development of comprehensive strategies, on the one hand, and specific decision making, on the other hand, and is therefore scalable from the neighborhood to the parcel level.

To conclude, the ResourcePlan helps to assess resource efficiency inter-disciplinarily, supports the spatial identification of synergies and conflicting goals, and contributes to transparent, resource-optimized planning decisions. The ResourcePlan will only develop its full impact when it is implemented consistently and over the long term in the municipal structures as a control element. Ongoing inter-disciplinary cooperation is essential and must always be continued. In the next step, the instrument must be extensively tested for further evaluation and optimization. The further investigations should strengthen the practicability, the effort, the transferability and the planning and legally binding nature of the ResourcePlan.

Supplementary Materials: The following supporting information can be downloaded at: https: / / www.mdpi.com/article/10.3390/su14031522/s1, S1: Empirical study on the integration of resource protection in current legal structures.

Author Contributions: Conceptualization, B.H., A.S.-R., J.N., R.A. and M.U.; methodology, B.H., A.S.-R., J.N., R.A., J.K., C.K. and C.J.S.; software, B.H., A.S.-R., J.K., C.K., C.J.S. and J.B.; validation, B.H., A.S.-R., J.N., R.A., J.K., C.K., C.J.S. and J.B.; formal analysis, B.H., A.S.-R., J.N., R.A., J.K., C.K., C.J.S. and J.B.; investigation, B.H., A.S.-R., J.N., R.A., J.K., C.K., C.J.S., W.G.-S. and J.B.; data curation, B.H., A.S.-R., J.N., R.A., J.K., C.K., C.J.S., W.G.-S. and J.B.; writing-original draft preparation, B.H., 
A.S.-R., J.N., R.A., J.K., C.K., C.J.S. and M.U.; writing-review and editing, C.R., W.G.-S., D.W., V.B., M.F., J.H., P.V., G.W. and S.F.; visualization, B.H. and A.S-R.; supervision, M.U. and B.H.; project administration, B.H. and M.U.; funding acquisition, M.U. All authors have read and agreed to the published version of the manuscript.

Funding: This research was funded by the German Federal Ministry of Education and Research $(\mathrm{BMBF})$ as part of the collaborative research project "Resource planning for urban districts" (R2Q), grant number FKZ 033W102. The project was part of the Research Cluster "Resource-efficient Urban Districts" (RES:Z), which belonged to the section "Research for sustainability" (FONA) of the BMBF.

Institutional Review Board Statement: Not applicable.

Informed Consent Statement: Not applicable.

Data Availability Statement: Data sharing not applicable.

Conflicts of Interest: The authors declare no conflict of interest.

\section{References}

1. WBGU. Humanity on the Move: Unlocking the Transformative Power of Cities: Flagship Report; German Advisory Council on Global Change (WGBU), Ed.; WGBU: Berlin/Heidelberg, Germany, 2016; ISBN 978-3-936191-45-5.

2. Honrado, J.P.; Vieira, C.; Soares, C.; Monteiro, M.B.; Marcos, B.; Pereira, H.M.; Partidário, M.R. Can We Infer about Ecosystem Services from EIA and SEA Practice? A Framework for Analysis and Examples from Portugal. Environ. Impact Assess. Rev. 2013, 40, 14-24. [CrossRef]

3. Węziak-Białowolska, D. Quality of Life in Cities-Empirical Evidence in Comparative European Perspective. Cities 2016, 58, 87-96. [CrossRef]

4. MEA. Living Behind Our Means: Natural Assets and Human Well-Being. Statement from the Board; Millennium Ecosystem Assessment Board, Ed.; Millennium Ecosystem Assessment Board: Washington, DC, USA, 2005.

5. Rockström, J.; Steffen, W.; Noone, K.; Persson, Å.; Chapin, F.S.; Lambin, E.F.; Lenton, T.M.; Scheffer, M.; Folke, C.; Schellnhuber, H.J.; et al. A Safe Operating Space for Humanity. Nature 2009, 461, 472-475. [CrossRef] [PubMed]

6. Steffen, W.; Richardson, K.; Rockstrom, J.; Cornell, S.E.; Fetzer, I.; Bennett, E.M.; Biggs, R.; Carpenter, S.R.; de Vries, W.; de Wit, C.A.; et al. Planetary Boundaries: Guiding Human Development on a Changing Planet. Science 2015, 347, 1259855. [CrossRef]

7. Seto, K.C.; Fragkias, M.; Güneralp, B.; Reilly, M.K. A Meta-Analysis of Global Urban Land Expansion. PLoS ONE 2011, 6, e23777. [CrossRef]

8. Grimm, N.B.; Faeth, S.H.; Golubiewski, N.E.; Redman, C.L.; Wu, J.; Bai, X.; Briggs, J.M. Global Change and the Ecology of Cities. Science 2008, 319, 756-760. [CrossRef]

9. IEA. World Energy Outlook 2018; International Energy Agency (IEA), Ed.; IEA Publications: Paris, France, 2018; ISBN 978-92-64-30677-6

10. Zommers, Z.; Wrathall, D.; van der Geest, K. Loss and Damage to Ecosystem Services; UNU-EHS Working Paper Series; United Nations University Institute of Environment and Human Security: Bonn, Germany, 2014; Volume 2.

11. Costanza, R.; de Groot, R.; Sutton, P.; van der Ploeg, S.; Anderson, S.J.; Kubiszewski, I.; Farber, S.; Turner, R.K. Changes in the Global Value of Ecosystem Services. Glob. Environ. Change 2014, 26, 152-158. [CrossRef]

12. UCCRN. The Future We Don't Want. How Climate Change Could Impact the World's Greatest Cities; Urban Climate Change Research Network (UCCRN), Ed.; UCCRN Technical Report; Urban Climate Change Research Network: London, UK, 2018.

13. C40. Deadline 2020: How Cities Will Get the Job Done. An Analysis of the Contribution C40 Cities Can Make to Delivering the Paris Agreement Objective of Limiting Global Temperature Rise to 1.5 Degrees; C40 Cities Climate Leadership Group, Ed.; C40 Cities Climate Leadership Group (C40): London, UK, 2016.

14. Adams, W.M. The Future of Sustainability: Re-Thinking Environment and Development in the Twenty-First Century. Report of the IUCN Renowned Thinkers Meeting, 29-31 January 2006; The World Conservation Union, Ed.; The World Conservation Union: Cambridge, UK, 2006.

15. The World Conservation Union. The IUCN Programme 2005-2008: Many Voices, One Earth, Adopted at the World Conservation Congress, Bangkok, Thailand, 17-25 November 2004; The World Conservation Union: Bangkok, Thailand, 2005.

16. United Nations (UN). Resolution Adopted by the General Assembly on 25 September 2015: Transforming Our World: The 2030 Agenda for Sustainable Development; United Nations: New York, NY, USA, 2015.

17. Leipzig Charter. Leipzig Charter on Sustainable European Cities; Ministerial Meeting on Urban Development and Territorial Cohesion, Ed.; Ministerial Meeting on Urban Development and Territorial Cohesion: Leipzig, Germany, 2007.

18. Leipzig Charter. The New Leipzig Charter-The Transformative Power of Cities for the Common Good; Ministerial Meeting on Urban Development and Territorial Cohesion, Ed.; Ministerial Meeting on Urban Development and Territorial Cohesion: Leipzig, Germany, 2020.

19. United Nations (UN). New Urban Agenda; United Nations, Habitat III Secretariat: Quito, Ecuador, 2017; ISBN 978-92-1-132731-1.

20. United Nations (UN). Paris Agreement. Int. Leg. Mater. 2016, 55, 740-755. [CrossRef]

21. European Comission. The European Green Deal; European Comission: Brussels, Belgium, 2019. 
22. Kosmol, J.; Kanthak, J.; Herrmann, F.; Golde, M.; Alsleben, C.; Penn-Bressel, G.; Schmitz, S.; Gromke, U. Resource Protection Glossary; Federal Environment Agency, Ed.; Federal Environment Agency Press Office: Dessau-Rosslau, Germany, 2012.

23. Arnfield, A.J. Two Decades of Urban Climate Research: A Review of Turbulence, Exchanges of Energy and Water, and the Urban Heat Island. Int. J. Climatol. 2003, 23, 1-26. [CrossRef]

24. IWA. The IWA Principles for Water-Wise Cities-For Urban Stakeholders to Develop a Shared Vision and Act towards Sustainable Urban Water in Resilient and Liveable Cities, 2nd ed.; International Water Association (IWA): London, UK, 2016.

25. Fletcher, T.D.; Shuster, W.; Hunt, W.F.; Ashley, R.; Butler, D.; Arthur, S.; Trowsdale, S.; Barraud, S.; Semadeni-Davies, A.; BertrandKrajewski, J.-L.; et al. SUDS, LID, BMPs, WSUD and More-The Evolution and Application of Terminology Surrounding Urban Drainage. Urban Water J. 2015, 12, 525-542. [CrossRef]

26. DWA. DWA Positions: Watersensitive Development of Our Cities; German Association for Water, Wastewater and Waste e. V. (DWA), Ed.; DWA-Positionen; German Association for Water, Wastewater and Waste e. V. (DWA): Hennef, Germany, 2021.

27. Otterpohl, R.; Braun, U.; Oldenburg, M. Innovative Technologies for Decentralised Water-, Wastewater and Biowaste Management in Urban and Peri-Urban Areas. Water Sci. Technol. 2004, 48, 23-32. [CrossRef]

28. Bosteels, T.; Sweatman, P.; Buckley, N.; Frankel, A.; Gray-Donald, J.; Griffin, R.; Hovorka, F.; Kamelgarn, Y.; Lorenz, D.; Reid, N.; et al. Sustainable Real Estate Investment: Implementing the Paris Climate Agreement: An Action Framework; CERES, IIGCC, IGCC, PRI, RICS, UNEP FI: New York, NY, USA, 2016.

29. Blasenbauer, D.; Bogush, A.; Carvalho, T.; Cleall, P.; Cormio, C.; Guglietta, D.; Fellner, J.; Fernández-Alonso, M.; Heuss-Aßbichler, S.; Huber, F; et al. Knowledge Base to Facilitate Anthropogenic Resource Assessment; Technische Universität Wien Research Center for Waste and Resource Management: Vienna, Austria, 2020. [CrossRef]

30. Deetman, S.; Marinova, S.; van der Voet, E.; van Vuuren, D.P.; Edelenbosch, O.; Heijungs, R. Modelling Global Material Stocks and Flows for Residential and Service Sector Buildings towards 2050. J. Clean. Prod. 2020, 245, 118658. [CrossRef]

31. Huber, R. Environmental Asessment of Management Options of the Urban Minaeral Building Stock. Available online: https: //www.irbnet.de/daten/iconda/CIB2738.pdf (accessed on 15 November 2021).

32. Bach, V.; Berger, M.; Henßler, M.; Kirchner, M.; Leiser, S.; Mohr, L.; Rother, E.; Ruhland, K.; Schneider, L.; Tikana, L.; et al. Integrated Method to Assess Resource Efficiency-ESSENZ. J. Clean. Prod. 2016, 137, 118-130. [CrossRef]

33. Patterson, M.G. What Is Energy Efficiency? Concepts, Indicators and Methodological Issues. Energy Policy 1996, 24, 377-390. [CrossRef]

34. Brischke, L.-A.; Thomas, S.; Baedeker, C.; Duscha, M.; Jacobsen, S.; Schmitt, C.; Spitzner, M.; Thema, J. Energy Sufficiency in the Context of Sustainability. Definition and Theory. Working Paper in the Context of the Project "Strategies and Instruments for a Technical, Systemic and Cultural Transformation to Sustainably Limit Energy Demand in the Consumer Field of Construction/Housing"; Institut für Energie- und Umweltforschung Heidelberg: Dortmund, Germany, 2014.

35. Darby, S.; Fawcett, T. Energy Sufficiency: An Introduction. Concept Paper; Environmental Change Institute, University of Oxford, Ed.; European Council for an Energy-Efficient Economy: Oxford, UK, 2018.

36. Samadi, S.; Gröne, M.-C.; Schneidewind, U.; Luhmann, H.-J.; Venjakob, J.; Best, B. Sufficiency in Energy Scenario Studies: Taking the Potential Benefits of Lifestyle Changes into Account. Technol. Forecast. Soc. Chang. 2017, 124, 126-134. [CrossRef]

37. Federal Ministry of Justice and Consumer Protection Germany. Federal Building Code; Federal Ministry of Justice and Consumer Protection Germany: Berlin/Heidelberg, Germany, 2017.

38. Federal Ministry of Justice and Consumer Protection Germany. Federal Nature Conservation Act; Federal Ministry of Justice and Consumer Protection Germany: Berlin/Heidelberg, Germany, 2009.

39. German Parliament. Scientific Services 7: Civil, criminal and procedural law, environmental protection law, construction and urban development. In Biotope Value Method in Germany; WD 7-3000-236-18; Scientific Services; German Parliament: Berlin/Heidelberg, Germany, 2018.

40. Dryzek, J.S. The Politics of the Earth; Oxford University Press: Oxford, UK, 2021; ISBN 0-19-885174-X.

41. Adams, B. Green Development: Environment and Sustainability in a Developing World, 4th ed.; Routledge: London, UK, 2019; ISBN 0-203-38603-5.

42. Jones, P. Growing Pacific Towns and Cities: Samoa's New Planning and Urban Management System. Aust. Plan. 2002, 39, 186-193. [CrossRef]

43. Bellamy, J.A.; Mcdonald, G.T.; Syme, G.J.; Butterworth, J.E. Policy Review Evaluating Integrated Resource Management. Soc. Nat. Resour. 1999, 12, 337-353. [CrossRef]

44. ISO 14044; 2006 Environmental Management-Life Cycle Assessement-Requirements and Guidelines. International Standard Organization: Geneva, Switzerland, 2006.

45. ISO 14040; Environmental Management-Life Cycle Assessment_Principles and Framework. International Standard Organization: Geneva, Switzerland, 2006.

46. Daxbeck, H.; Buschmann, H.; Gassner, A.; Kapfenberger-Pock, A. The Anthropogenic Stock in Styria-Development of an Urban Mining Cadastre. Province of Styria Including Case Study Graz. Project UMKAT. Final Report; Ressourcen Management Argentur: Vienna, Austria, 2015.

47. Kleemann, F. Buildings as Potential Urban Mines: Quantitative, Qualitative and Spatial Analysis for Vienna; Faculty of Civil Engineering, Technische Universität Wien: Vienna, Austria, 2016. 
48. Augiseau, V.; Barles, S. Studying Construction Materials Flows and Stock: A Review. Resour. Conserv. Recycl. 2016, 123, 153-164. [CrossRef]

49. Meneses, M.; Pasqualino, J.C.; Castells, F. Environmental Assessment of Urban Wastewater Reuse: Treatment Alternatives and Applications. Chemosphere 2010, 81, 266-272. [CrossRef]

50. European Environmental Agency. Performance of Water Utilities beyond Compliance; European Environmental Agency: København, Denmark, 2014.

51. Lautenschläger, S.; Laforet, L.; Schimpke, J.; Holländer, R.; Töws, I.; Böttger, S.; Stich, G.; Lange, A. Analysis and Evaluation of the Sustainability and Eco-Efficiency of Small Wastewater Treatment Plants with Derivation of Product Improvements. Final Report; Tilia GmbH: Leipzig, Germany, 2016.

52. Matzinger, A.; Riechel, M.; Remy, C.; Schwarzmüller, H.; Rouault, P.; Schmidt, M.; Offermann, M.; Strehl, C.; Nickel, D.; Pallasch, M.; et al. Target-Oriented Planning of Stormwater Management Measures-Results of the KURAS Project; KURAS-Leitfaden; Kompetenzzentrum Wasser Berlin gGmbH (KWB): Berlin/Heidelberg, Germany, 2017.

53. Norman, J.; MacLean, H.L.; Kennedy, C.A. Comparing High and Low Residential Density: Life-Cycle Analysis of Energy Use and Greenhouse Gas Emissions. J. Urban Plan. Dev. 2006, 132, 10-21. [CrossRef]

54. Lotteau, M.; Loubet, P.; Pousse, M.; Dufrasnes, E.; Sonnemann, G. Critical Review of Life Cycle Assessment (LCA) for the Built Environment at the Neighborhood Scale. Build. Environ. 2015, 93, 165-178. [CrossRef]

55. Lotteau, M.; Yepez-Salmon, G.; Salmon, N. Environmental Assessment of Sustainable Neighborhood Projects through NEST, a Decision Support Tool for Early Stage Urban Planning. Procedia Eng. 2015, 115, 69-76. [CrossRef]

56. Cremer, A.; Berger, M.; Müller, K.; Finkbeiner, M. The First City Organizational LCA Case Study: Feasibility and Lessons Learned from Vienna. Sustainability 2021, 13, 5062. [CrossRef]

57. Cremer, A.; Müller, K.; Berger, M.; Finkbeiner, M. A Framework for Environmental Decision Support in Cities Incorporating Organizational LCA. Int. J. Life Cycle Assess 2020, 25, 2204-2216. [CrossRef]

58. Mirabella, N.; Allacker, K.; Sala, S. Current Trends and Limitations of Life Cycle Assessment Applied to the Urban Scale: Critical Analysis and Review of Selected Literature. Int. J. Life Cycle Assess 2019, 24, 1174-1193. [CrossRef]

59. Susca, T.; Pomponi, F. Heat Island Effects in Urban Life Cycle Assessment: Novel Insights to Include the Effects of the Urban Heat Island and UHI-mitigation Measures in LCA for Effective Policy Making. J. Ind. Ecol. 2020, 24, 410-423. [CrossRef]

60. Della Spina, L.; Lorè, I.; Scrivo, R.; Viglianisi, A. An Integrated Assessment Approach as a Decision Support System for Urban Planning and Urban Regeneration Policies. Buildings 2017, 7, 85. [CrossRef]

61. Guarini, M.R.; Chiovitti, A.; Battisti, F.; Morano, P. An Integrated Approach for the Assessment of Urban Transformation Proposals in Historic and Consolidated Tissues; Springer International Publishing: Cham, Switzerland, 2017; pp. 562-574.

62. Berg, P.G.; Nycander, G. Sustainable Neighbourhoods-A Qualitative Model for Resource Management in Communities. Landsc. Urban Plan. 1997, 39, 117-135. [CrossRef]

63. Sprecher, B.; Verhagen, T.J.; Sauer, M.L.; Baars, M.; Heintz, J.; Fishman, T. Material Intensity Database for the Dutch Building Stock: Towards Big Data in Material Stock Analysis. J. Ind. Ecol. 2021. [CrossRef]

64. Klemm, C.; Vennemann, P. Modeling and Optimization of Multi-Energy Systems in Mixed-Use Districts: A Review of Existing Methods and Approaches. Renew. Sustain. Energy Rev. 2021, 135, 110206. [CrossRef]

65. Wu, T.; Song, H.; Wang, J.; Friedler, E. Framework, Procedure, and Tools for Comprehensive Evaluation of Sustainable Stormwater Management: A Review. Water 2020, 12, 1231. [CrossRef]

66. Kuller, M.; Farrelly, M.; Deletic, A.; Bach, P.M. Building Effective Planning Support Systems for Green Urban Water InfrastructurePractitioners' Perceptions. Environ. Sci. Policy 2018, 89, 153-162. [CrossRef]

67. Sucu, S.; van Schaik, M.O.; Esmeli, R.; Ouelhadj, D.; Holloway, T.; Williams, J.B.; Cruddas, P.; Martinson, D.B.; Chen, W.-S.; Cappon, H.J. A Conceptual Framework for a Multi-Criteria Decision Support Tool to Select Technologies for Resource Recovery from Urban Wastewater. J. Environ. Manag. 2021, 300, 113608. [CrossRef] [PubMed]

68. Parsaee, M.; Joybari, M.M.; Mirzaei, P.A.; Haghighat, F. Urban Heat Island, Urban Climate Maps and Urban Development Policies and Action Plans. Environ. Technol. Innov. 2019, 14, 100341. [CrossRef]

69. Nuissl, H.; Haase, D.; Lanzendorf, M.; Wittmer, H. Environmental Impact Assessment of Urban Land Use Transitions-A Context-Sensitive Approach. Land Use Policy 2009, 26, 414-424. [CrossRef]

70. Shepherd, A.; Ortolano, L. Strategic Environmental Assessment for Sustainable Urban Development. Environ. Impact Assess. Rev. 1996, 16, 321-335. [CrossRef]

71. Ren, C.; Spit, T.; Lenzholzer, S.; Yim, H.L.S.; Heusinkveld, B.; van Hove, B.; Chen, L.; Kupski, S.; Burghardt, R.; Katzschner, L. Urban Climate Map System for Dutch Spatial Planning. Int. J. Appl. Earth Obs. Geoinf. 2012, 18, 207-221. [CrossRef]

72. Cortinovis, C.; Geneletti, D. Ecosystem Services in Urban Plans: What Is There, and What Is Still Needed for Better Decisions. Land Use Policy 2018, 70, 298-312. [CrossRef]

73. Bina, O. Strategic Environmental Assessment. In Innovation in Environmental Policy? Integrating Environment for Sustainability; Jordan, A., Lenschow, A., Eds.; Edward Elgar Publishing: Cheltenham, UK, 2008; pp. 134-156. ISBN 978-1-84844-506-2.

74. King, H.; Smith, L. Many Rivers to Cross: Evaluating the Benefits and Limitations of Strategic Environmental Assessment for the Koshi River Basin. J. Env. Assmt. Pol. Mgmt. 2016, 18, 1650011. [CrossRef]

75. Lobos, V.; Partidario, M. Theory versus Practice in Strategic Environmental Assessment (SEA). Environ. Impact Assess. Rev. 2014, 48, 34-46. [CrossRef] 
76. Schnur, O.; Gebhard, D. Neighborhood Research: Between Theory and Practice; VS research. Quartiersforschung; 1 . Aufl.; VS Verlag für Sozialwissenschaften: Wiesbaden, Germany, 2008; ISBN 978-3-531-16098-6.

77. Grates, M.; Krön, A.; Rüßler, H. Urban Neighborhoods: Understanding Framework Conditions and Capturing the Initial Conditions; Handbuchreihe "Ältere als (Ko-)Produzenten von Quartiersnetzwerken-Impulse aus dem Projekt QuartiersNETZ"; Fachhochschule Dortmund, Forschungsinstitut Geragogik: Dortmund, Germany, 2018.

78. Open Street Map. Available online: http:/ / www.openstreetmap.org/ (accessed on 20 January 2018).

79. Creative Commons Licenses CC-BY-SA 2.0. Available online: https://creativecommons.org/licenses/by-sa/2.0/ (accessed on 20 January 2018).

80. Gillingham, K.; Newell, R.G.; Palmer, K. Energy Efficiency Economics and Policy. Annu. Rev. Resour. Econ. 2009, 1, 597-620. [CrossRef]

81. Jaccard, M. Sustainable Fossil Fuels: The Unusual Suspect in the Quest for Clean and Enduring Energy; Cambridge University Press: Cambridge, UK; New York, NY, USA, 2006; ISBN 1-139-44905-2.

82. National Geographic Society; Rutledge, K.; Ramroop, T.; Boudreau, D.; McDaniel, M.; Teng, S.; Sprout, E.; Costa, H.; Hall, H. Jeff Hunt Urban Area: An Urban Area Is the Region Surrounding a City. Available online: http:/ /www.nationalgeographic.org/ encyclopedia/urban-area/ (accessed on 30 November 2021).

83. Klemm, C.; Wiese, F. Indicators for the Optimization of Sustainable Urban Energy Systems Based on Energy System Modeling. Energy Sustain. Soc. 2022, 12, 3. [CrossRef]

84. Carreón, J.R.; Worrell, E. Urban Energy Systems within the Transition to Sustainable Development. A Research Agenda for Urban Metabolism. Resour. Conserv. Recycl. 2018, 132, 258-266. [CrossRef]

85. Suchanek, A.; Lin-Hi, N.; Piekenbrock, D. What Is "Benefit"? Available online: https:/ / wirtschaftslexikon.gabler.de/definition/ nutzen-41854/version-384756 (accessed on 30 November 2021).

86. Bezirksregierung Köln Geodaten NRW. Available online: https://www.opengeodata.nrw.de/produkte/ (accessed on 1 February 2021).

87. Data Licence Germany-Zero-Version 2.0. Available online: https://www.govdata.de/dl-de/zero-2-0 (accessed on 1 December 2021).

88. European Union. Consolidated Version of the Treaty on the Functioning of the European Union-Part three: Union policies and internal actions-Title xx: Environment-Article 191. Off. J. Eurpean Union 2008, 115, 0132-0133.

89. Federal Ministry of Environment, Nature Conservation, Building and Nuclear Safety Germany. German Resource Efficiency Programme, ProgRess; Federal Ministry of Environment, Nature Conservation, Building and Nuclear Safety Germany: Berlin/Heidelberg, Germany, 2020.

90. Ministry of the Interior of the State of North Rhine-Westphalia. Recast Climate Protection Act North Rine-Westphalia; Ministry of the Interior of the State of North Rhine-Westphalia: Düsseldorf, Germany, 2021.

91. Li, J.; Xiao, F.; Zhang, L.; Amirkhanian, S.N. Life Cycle Assessment and Life Cycle Cost Analysis of Recycled Solid Waste Materials in Highway Pavement: A Review. J. Clean. Prod. 2019, 233, 1182-1206. [CrossRef]

92. Matthey, A.; Bünger, B. Method Convention 3.1 for the Determination of Environmental Costs. Cost Factors. Status 12/2020; Umweltbundesamt, Ed.; Umweltbundesamt: Dessau-Rosslau, Germany, 2020; ISBN 1862-4804.

93. DWA; DVGW. Guidelines for Performing Dynamic Cost Comparison Calculations (KVR Guidelines); German Association for Water, Wastewater and Waste e. V. (DWA): Hennef, Germany, 2012; ISBN 978-3-941897-55-7.

94. DWA-A 100. Guidelines for Integrated Urban Drainage; German Association for Water, Wastewater and Waste e. V. (DWA): Hennef, Germany, 2006; ISBN 978-3-939057-70-3.

95. Henrichs, M.; Langner, J.; Uhl, M. Development of a Simplified Urban Water Balance Model (WABILA). Water Sci. Technol. 2016, 73, 1785-1795. [CrossRef]

96. Hörnschemeyer, B.; Henrichs, M.; Uhl, M. SWMM-UrbanEVA: A Model for the Evapotranspiration of Urban Vegetation. Water 2021, 13, 243. [CrossRef]

97. Kisser, J.; Wirth, M.; De Gusseme, B.; Van Eekert, M.; Zeeman, G.; Schoenborn, A.; Vinnerås, B.; Finger, D.C.; Kolbl Repinc, S.; Bulc, T.G.; et al. A Review of Nature-Based Solutions for Resource Recovery in Cities. Blue-Green Syst. 2020, 2, 138-172. [CrossRef]

98. Schütze, M.; Wriege-Bechtold, A.; Zinati, T.; Söbke, H.; Wißmann, I.; Schulz, M.; Veser, S.; Londong, J.; Barjenbruch, M.; Alex, J. Simulation and Visualization of Material Flows in Sanitation Systems for Streamlined Sustainability Assessment. Water Sci. Technol. 2019, 79, 1966-1976. [CrossRef]

99. Fuso Nerini, F.; Tomei, J.; To, L.S.; Bisaga, I.; Parikh, P.; Black, M.; Borrion, A.; Spataru, C.; Castán Broto, V.; Anandarajah, G.; et al. Mapping Synergies and Trade-Offs between Energy and the Sustainable Development Goals. Nat. Energy 2018, 3, 10-15. [CrossRef]

100. Marquez-Ballesteros, M.-J.; Mora-López, L.; Lloret-Gallego, P.; Sumper, A.; Sidrach-de-Cardona, M. Measuring Urban Energy Sustainability and Its Application to Two Spanish Cities: Malaga and Barcelona. Sustain. Cities Soc. 2019, 45, 335-347. [CrossRef]

101. Emec, S.; Bilge, P.; Seliger, G. Design of Production Systems with Hybrid Energy and Water Generation for Sustainable Value Creation. Clean Technol. Environ. Policy 2015, 17, 1807-1829. [CrossRef]

102. Klemm, C.; Budde, J.; Becker, G.; Wittor, Y.; Vennemann, P. The Spreadsheet Energy System Model Generator-SESMG 0.1.1 Documentation. Available online: https://spreadsheet-energy-system-model-generator.readthedocs.io/en/latest/ (accessed on 1 December 2021). 